\title{
UN TIPAR DE PIATRĂ DIN SECOLELE VI-VII P.CHR. DESCOPERIT ÎN AŞEZAREA DE LA BuCUREŞTI-B̆̈NEASA, STR. GÂRLEI
}

RODICA OANȚĂ-MARGHITU
SORIN OANȚĂ-MARGHITU

\section{REZUMAT:}

Articolul discută un tipar de turnare descoperit în anul 2013 în situl de la București-Băneasa, Str. Gârlei. Pe baza analogiilor, tiparul se datează în secolele VI-VII p.Chr., perioadă bine reprezentată în acest sit printr-un număr mare de construcții adâncite. În condițiile în care lucrările agricole au afectat întreg situl, distrugând eventualele niveluri de locuire, precum și părțile superioare ale construcțiilor adâncite, este dificil de stabilit contextul în care a fost abandonat tiparul. Piesa putea fi folosită pentru turnarea unor aliaje de staniu și/sau plumb cu puncte de topire scăzute și pentru obținerea unor artefacte de mici dimensiuni, folosite ori ca piese de sine stătătoare ori ca elemente integrate ulterior în structura unor podoabe sau accesorii mai elaborate. Prin particularitățile sale, tiparul ne permite să surprindem un ecou îndepărtat al podoabelor din metale prețioase bogat ornamentate cu granulație, estetica noilor piese păstrându-și valențele decorative în pofida valorii reduse a materiilor prime folosite și a originalităţii abordării tehnologice.

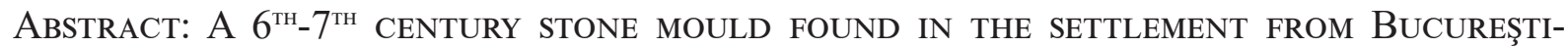 BĂNEASA, STR. GÂrLeI}

This paper reports on a casting mould discovered in 2013 at the archaeological site from Băneasa, Str. Gârlei (Bucharest, Romania). Based on archaeological analogies, the mould was dated to the $6^{\text {th }} 7^{\text {th }}$ centuries $A D$, a time period well represented at this archaeological site by a large number of pit dwellings. As the agricultural works had affected the entire site destroying the possible occupation levels, as well as the upper layers of the pit dwellings, it was difficult to establish the context in which the mould was abandoned. The object might have been used to cast certain tin and/or lead alloys with low melting points in order to manufacture small size items used as stand-alone artefacts or as elements subsequently reassembled in the structure of more complex adornments. The distinct features of this mould retain the remote echo of adornments made from precious metals, richly decorated by granulation, while preserving the decorative merits regardless the reduced value of the raw materials, and of the originality of the technological approach.

CuvinTE CHEIE: București, evul mediu timpuriu, secolele VI-VII p.Chr., tipar de turnare, aliaje de staniu și plumb

KEYWORDS: Bucharest, Early Middle Ages, $6^{\text {th }}-7^{\text {th }}$ century AD, casting mould, tin-lead alloys

\section{Contextul descoperirii}

În anii 2008 şi 2013, Muzeul Național de Istorie a României a efectuat săpături arheologice preventive în situl de la București-Băneasa, Str. Gârlei, situat pe malul nordic al actualului Lac Băneasa (P1. I-II) ${ }^{1}$. Aspectul peisajului contemporan este rezultatul amplelor lucrări desfășurate de-a lungul timpului pentru amenajarea cursului Colentinei într-o salbă de lacuri. Înainte de transformările suferite în modernitate, ,,peninsula” de astăzi era de fapt un teren delimitat de un meandru al râului. Terenul cu o suprafaţă de peste 10 ha a aparținut fostei Stațiuni Centrale de Cercetare pentru Cultura și Industrializarea Tutunului (moștenitoare a Institutului Experimental pentru Cultivarea și Fermentarea Tutunului înființat în anul 1925 printr-un decret al ministrului de finanțe din acea perioadă, Vintilă Brătianu). Lucrările agricole efectuate anual până la sfârșitul anilor 1990, când staţiunea de cercetare a fost desființată, au determinat o anumită „estetică” a dăinuirii urmelor materiale ale trecutului. Conform unui studiu efectuat de Institutul de Cercetări pentru Pedologie și Agrochimie, în anul 2000 încă se mai recunoșteau

\footnotetext{
Damian et al. 2014; Oanţă-Marghitu S. et al. 2016.
} 
pe suprafața terenului urmele arăturilor ${ }^{2}$. Terenul, suprafertilizat cu nitrați și cultivat cu tutun din soiul Bărăgan, a fost caracterizat în termeni conciși: „Biotop: teren plan, mecanizat 100\%”’3. De altfel, săpăturile arheologice au surprins urmele acestor arături sub forma unor dungi paralele, ,imprimate” în depunerea naturală de argilă galbenă. În aceste condiții, colectivul de cercetare a optat pentru o săpătură în suprafaţă a sitului; decaparea s-a efectuat mecanic utilizând un excavator cu cupă de taluz care a permis obținerea unor răzuieli cu acuratețe suficientă pentru a identifica și delimita complexele. Săpăturile arheologice au surprins doar resturile unei ,arhitecturi subterane”, mai precis, părțile inferioare ale unor construcții adâncite și gropi cu diferite funcționalităţi, datate în diferite epoci și perioade istorice: neolitic, epoca bronzului, a doua epocă a fierului, evul mediu timpuriu (secolele VI-VII p.Chr.), evul mediu târziu (secolul al XVIII-lea), trecutul recent şi apropiat.

Depunerea de argilă galbenă era suprapusă de un strat cenuşiu, de grosime variabilă, supus nivelării în vederea parcelării terenului prin amenajarea a două ,valuri”, unul care străbate peninsula longitudinal, de la NE la SV, și celălalt, orientat E-V care îl intersectează pe primul (Pl. II/1). Lucrările au afectat întreg stratul, distrugând eventualele niveluri de locuire, precum și părțile superioare ale construcțiilor adâncite. Obiecte contemporane (cioburi de sticlă, bucăți de sfoară) au fost descoperite atât la limita dintre stratul cenușiu și depunerea de argilă, cât și, în câteva cazuri, puțin deasupra vetrelor aparținând cuptoarelor distruse ale unor construcții adâncite. În stratul cenuşiu, obiectele din trecutul recent și apropiat erau asociate cu piese din diferitele epoci şi perioade reprezentate de complexele cercetate în sit: fragmente de lipituri, vălătuci și cărămizi, fragmente ceramice de factură ,preistorică” și cioburi smălţuite, fusaiole și piese industriale, monede din secolele XIX-XX.

Dintre aceste obiecte reține atenția un tipar de piatră (MNIR nr. inv. 378564) (Pl. III/1-2, IV/1) descoperit în anul 2013 în stratul cenușiu care suprapunea gropile C635 și C636, ambele având în umplutură fragmente ceramice din a doua epocă a fierului. Tiparul a fost folosit pentru turnarea unor elemente de mici dimensiuni utilizate individual sau integrate ulterior în structura unor piese mai elaborate. Pentru realizarea tiparului a fost ales un şist argilos fin, cu mica foarte fină, foarte omogen, moderat compact, foarte bine sortat, de culoare brun-gălbuie (cafeniu deschis) ${ }^{4}$.

Pe baza analogiilor, tiparul poate fi încadrat în evul mediu timpuriu, secolele VI-VII p.Chr. Această perioadă este reprezentată în situl de la București-Băneasa, Str. Gârlei de o rețea formată din 85 complexe (numărul este provizoriu, materialul fiind încă în curs de prelucrare; de asemenea, nu este exclus ca unele complexe să se încadreze într-o perioadă mai târzie): 77 de construcții adâncite în depunerea de argilă galbenă, cu gropile de formă rectangulară sau ovală având diferite orientări, șapte gropi cu caracter menajer care pot fi încadrate, cu mare probabilitate, în această perioadă doar pe baza prezenței unor fragmente de vălătuci în umplutură și o groapă circulară, cu profilul în formă de clopot și pereții arși la roșu. Construcțiile aveau cuptoare amenajate în două stiluri, fie săpate direct într-un perete al gropii, fie într-un bloc de lut cruțat în interior. În condițiile în care nu s-a păstrat nivelul de săpare a gropilor acestor construcții, este dificil de stabilit contextul în care a fost abandonat tiparul. Trebuie menționat faptul că, în multe cazuri, ceramica prezintă un indice mare de fragmentare și este prezentă la diferite adâncimi în umplutura gropii construcțiilor, observație care ar sugera o practică de transformare a spaţiului abandonat în loc de depunere a obiectelor scoase din uz și, eventual, a resturilor menajere. Această schimbare de semnificație a construcțiilor, de la structură de locuire la loc de depunere, poate explica numărul mic al gropilor menajere din această perioadă. Ca urmare, ținând cont de particularităţile sitului, nu s-a putut preciza apartenenţa tiparului la un context bine definit.

\section{Descriere (PI. III, IV/1)}

Tiparul are o formă cvasi dreptunghiulară cu o lungime de 10,21 cm și 4,65 cm lăţime la unul dintre capete și 3,68 cm la celălalt, grosimea plăcii de piatră (argilit) variind între 10,31 și $11,30 \mathrm{~cm}$. Piatra este atent șlefuită, fețele fiind aproape lucioase. Deși urmele de ardere care se pot observa pe ambele fețe sugerează faptul că era un element dintr-o suită de mai multe plăci suprapuse, piesa are o singură față activă. Pe aceasta se disting două pâlnii de turnare bine definite (A și B) şi două mai superficial conturate (C și D). Pâlnia A, dezvoltată de-a lungul plăcii, are patru ramificații clare și una doar schițată sumar, a, b, c, d și e, una dintre acestea împărțindu-se la rândul său în două, b1 și b2. La capetele acestor ramificații au fost incizate patru mici rozete, practic grupaje de șase sau cinci excavații mici, semisferice, dispuse împrejurul unui canal circular sub forma unor „flori” cu șase (pe canalele a, c şi d) sau cinci petale (pe canalul b2). La capătul braţului b1 este gravat un canal circular continuat cu un ciorchine de 12 excavații mici, semisferice $(\mathrm{D}: \approx 1,2 \mathrm{~mm}$ ), unele mai bine și altele mai slab definite, cu o cavitate mai mare (D: $\approx 3 \mathrm{~mm}$ ) la capăt; excavațiile sunt grupate într-un triunghi ascuțit, cvasi-isoscel. Canalul c este doar parțial incizat, în jumătatea dinspre trunchiul comun, iar „floarea” cu șase petale către care se îndreaptă nu este

Dumitru et al. 2000, 5; Damian et al. 2014, 166.

Dumitru et al. 2000, 10 .

Descrierea tehnică a rocii este realizată de domnul Dr. Constantin Haită. 
în mod direct conectată cu acesta. Există în schimb o amprentă, uşor afumată, care sugerează traiectoria și forma canalului pe tiparul pereche. Chiar dacă, judecând strict din perspectiva piesei păstrate, în această zonă tiparul pare nefuncțional, împreună cu jumătatea suprapusă forma o pereche perfect funcțională, meșterul adaptând formele sculptate pe plăcile de piatră în funcție de elementele pe care dorea să le obțină: sârme cu secțiunea circulară prin sculptarea ambelor fețe ale perechii de tipare - sau sârme cu secțiunea în formă de D - prin sculptarea unei singure fețe. Un alt detaliu interesant este faptul că, de fiecare dată, contactul dintre capătul canalului de turnare și elementele „florale” se realizează în zona uneia dintre ,petale”. La capătul ultimului canal, e, incizat superficial și foarte probabil nefuncțional, a fost desenat un contur în formă de picătură cu o mică excavație semisferică în vârf. În mod sugestiv, piatra nu este deloc afumată de-a lungul traiectoriei acestui canal.

Pâlnia de turnare B este dezvoltată pe lățime, subțiată într-un canal scurt, f, la capătul căruia a fost gravat un contur circular continuat cu un ciorchine format din 17 mici excavații semisferice (D între: $\approx 1,5 \mathrm{~mm}$ și $8 \mathrm{~mm}$ ) grupate întrun triunghi cvasi-echilateral cu latura de $\approx 9 \mathrm{~mm}$. Vârful triunghiului pare să fie unit de latura opusă a plăcii printr-o altă pâlnie de turnare, $\mathbf{C}$, mai superficial conturată. Este posibil ca această pâlnie să fi avut și funcția unui canal de ventilație. Interesant de sesizat ar fi şi faptul că, în cazul ambelor grupări triunghiulare, se poate bănui modul în care au fost realizate. Astfel, în ambele situații există o latură mai dreaptă și mai bine definită, cu adânciturile în mod regulat realizate. Totuși, ulterior, restul excavațiilor nu se mai grupează simetric, în mod regulat geometric, ci sunt destul de dezordonate. Detaliile evidențiază, în mod clar, o anumită neglijență a execuției. Pe suprafața acestei fețe, pe cea de-a doua latură scurtă a fost conturată o a patra pâlnie de turnare, D, care nu era însă funcțională, nefiind continuată cu niciun canal de turnare și neconducând către niciun profil gravat.

Pe reversul plăcii de piatră nu se mai observă alte excavații care ar fi putut fi folosite ca forme de turnare. Se observă totuși câteva particularități care oferă indicii referitoare la modul de utilizare a piesei. Pe una dintre laturile înguste, pe reversul zonei în care este adâncită pâlnia de turnare D, se poate observa o altă pâlnie de turnare, E. Deși aceasta nu se continuă cu alte canale, zona este totuși puternic afumată, fapt care sugerează funcționalitatea acesteia. Pe latura opusă se poate observa o spărtură, pe cant fiind foarte clar şi finisajul pâlniei de turnare, F, deteriorată însă din vechime. Urmele de ardere, înnegrite, sugerează o dezvoltare longitudinală, dinspre laturile înguste către centru, fiind mai puternice către capete și estompându-se treptat către centru. Ca urmare, presupunem că această față funcționa ca o suprafață plană deasupra unui alt tipar cu un contur asemănător pe care fuseseră sculptate alte canale și forme de tunare. Longitudinal, sunt vizibile mai multe zgârieturi, cele mai pronunțate pornind din zona pâlniei de turnare E. În apropierea spărturii se observă o excavație, o gaură circulară, amplasamentul său, la mică distanță de marginea piesei, sugerând rolul unei găuri de ghidaj (III?) sau intenția realizării acesteia. Zona corespunde amplasamentului găurii de ghidaj I dar placa de piatră nu este perforată și cele două elemente nu comunică între ele.

Pe laturile lungi se observă două găuri de ghidaj (I și II) în care se mai păstrează încă fragmente din tijele metalice care asigurau alinierea și unitatea suitei de tipare suprapuse. Găurile acestea nu au perforat însă în totalitate placa de piatră. Interesant de sesizat este faptul că perforațiile nu au fost făcute perpendicular pe fețele tiparului ci oblic, într-un unghi de aproximativ $45^{\circ}$. Privite de aproape, se poate observa fasonarea curată şi atentă a acestor perforații. Fiind realizate foarte aproape de marginile plăcii, acestea s-au rupt în momentul în care, după turnare, tiparele au fost desfăcute. În mod normal, acest tip de tipare se refoloseau, tijele sau barele introduse prin găurile de ghidaj putând fi scoase după finalizarea procesului de turnare și permițându-se astfel desfacerea valvelor. Dintre tiparele de turnare contemporane păstrate, acolo unde s-au putut identifica găuri de ghidaj, în unele cazuri acestea se păstrează sub forma unor găuri curate și în alte cazuri se observă încă resturi metalice. Ar trebui evidenţiat și faptul că pe suprafața acestui tipar nu se observă niciun canal de ventilație.

Aspectul de astăzi al tiparului nu reprezintă, foarte probabil, rezultatul unitar al unei singure folosiri sau al ultimei întrebuințări. Putem presupune că marginile plăcii au fost îndreptate o dată sau de mai multe ori, găurile de ghidaj aflate chiar pe margine putând fi un indiciu în acest sens. De asemenea, nu este obligatoriu ca zonele care astăzi sunt înnegrite să fi căpătat acest aspect în urma aceleiași întrebuinţări. Așa cum s-a observat și pe alte tipare, plăcile de piatră erau uneori refolosite 5 .

\section{Elemente obținute, analogii, sugestii de utilizare}

Judecând după forma micilor excavații realizate pe suprafața tiparului, acesta era utilizat pentru obținerea unor artefacte de mici dimensiuni, între 0,71 și $1,71 \mathrm{~cm}$, folosite ori ca piese de sine stătătoare ori ca elemente integrate ulterior în structura unor podoabe sau accesorii mai elaborate. Elementele aflate la capetele canalelor a, b2, c și d

\footnotetext{
5 Tiparul de la Argamum (Jurilovca, jud. Tulcea) este ilustrativ în acest sens. Una dintre fețe, deși păstrează gravate o serie de forme și un canal de ventilație, nu este funcțională fiind lipsită de pâlnia sau pâlniile de turnare. În schimb, cealaltă față era funcțională având bine definită pâlnia de turnare (Oanță-Marghitu R. 2006, 356).
} 
se concretizau sub forma unor mici verigi înconjurate de granule, forme pe care le-am putea vedea, de exemplu, anturând niște capete ornamentale de nit. Componente asemănătoare se observă pe fibula mare din tezaurul de la Coșovenii de Jos marcând ochii măștii umane și, tot acolo, pe cele patru ornamente granulate de pe piciorul fibulei ${ }^{6}$ (Pl. V/1-2). Elemente asemănătoare, verigi încadrate de șase granule, se obțineau și cu unul dintre tiparele de la Budureasca cat. 2 (Pl. IV/2/a, b, c, e), singura deosebire notabilă fiind faptul că, în cazul acesta, veriga centrală are un diametru puțin mai mare. Chiar și compoziția singulară, dezvoltată de-a lungul canalului c se regăsește întocmai și pe acest tipar de la Budureasca (Pl. IV/2 tot canalul c), singurele deosebiri fiind faptul că asocierea tijă-verigă în formă de picătură se află în partea opusă pâlniei de turnare, toate elementele fiind incizate în valva de tipar păstrată` Elementul obținut la capătul canalului b1 era un grupaj triunghiular de granule încadrat la bază de o verigă iar în vârf de o granulă mai mare. Același tip de componente ar fi putut fi obținute și cu un alt tipar de la Budureasca, cat. 9, descoperit în același context cu cel menționat anterior ${ }^{8}(\mathrm{Pl}$. IV/3/b, c, e). Deși profilul unor mici componente asemănătoare pare să fie recunoscut pe mai multe tipare diferite, descoperite în situri distincte, nu s-au identificat totuși piese în structura cărora să se recunoască în mod clar și repetitiv aceste detaliii'. Poate nu ar trebui fi exclusă și folosirea ca un artefact de sine stătător, elementul având și o mică verigă de suspensie. Caracteristicile sale ar fi permis, în egală măsură, utilizarea ca pandantiv, coaserea pe veșminte sau integrarea în structura unor șiraguri, indiferent care ar fi fost funcționalitatea acestora.

Elementul care se obținea la capătul canalului e, despre care nu putem spune cu siguranță dacă era funcțional sau nu, era o verigă în formă de picătură cu o granulă în vârf.

Elementul obținut între pâlniile de turnare $\mathbf{B}$ și $\mathbf{C}$, dezvoltate transversal pe tipar, era un ciorchine de granule, la bază cu o verigă cu D: $\approx 8 \mathrm{~mm}$. Ca și în situațiile anterioare, există posibilitatea folosirii ca un artefact în sine, înşirat, cusut sau altfel integrat în structura ornamentelor care decorau veșmintele sau alte tipuri de obiecte. Grupajele triunghiulare de granule reprezintă o constantă decorativă de-a lungul timpului putând fi regăsite pe diferite tipuri de podoabe și de accesorii. Dintre piesele care aparțin în mare aceleiași perioade, grupaje comparabile pot fi întâlnite, și în acest caz, pe piese din tezaurul de la Coşovenii de Jos, atât pe pandantivele stelate ale cerceilor cât și pe aplicațiile semisferice, ornamentate cu granulație, de pe piciorul fibulei (Pl. V/2, 3, 4). Cel mai bine se aseamănă însă cu grupajul din partea inferioară a cercelului identificat în colecțiile Muzeului Național de Istorie a României prin numărul de inventar 8710, 8711, 8712 (piesa a fost întregită și restaurată din mai multe fragmente și din această cauză are practic trei numere de inventar) (Pl. V/4).

Combinate câte trei, grupajele triunghiulare ar putea fi văzute și asamblând pandantivele piramidale ale cerceilor de tip Szegvár sau Deszk (Pl. IV/4, 5), din spațiul controlat de avari în zona Dunării mijlocii ${ }^{10}$. Chiar şi grupajele triunghiulare mai mici aflate pe tiparul de la București-Băneasa, Str. Gârlei la capătul canalului b1 iar pe cel de la Budureasca cat. 9 la capătul canalelor $\mathbf{b}, \mathbf{c} s ̧ i$ e ar fi putut fi folosite pentru obținerea unor elemente care să fi fost ulterior asamblate pentru a obține cercei cu un aspect comparabil cu cei din variantele menționate. Faptul că pe tiparul Budureasca cat. 9 grupajul triunghiular de granule este repetat de trei ori susține sugestia noastră. Se obțineau practic trei elemente, câte unul pentru fiecare față a piramidei.

Un tipar de turnare folosit probabil pentru obținerea unui pandantiv de cercel piramidal este cunoscut și de la Oescus (Gingen, Bulgaria) ${ }^{11}$. Prin intermediul mormântului de „călăreț” de la Szegvár-Sápoldal (Ungaria, com. Csongrád), din inventarul căruia s-a păstrat un astfel de cercel - cu pandantiv piramidal și cu suprafețele triunghiulare acoperite uniform cu granule - avem și un reper cronologic foarte clar, în gura defunctului fiind depusă o monedă de aur, o imitație contemporană, necirculată, a unui solidus emis de Mauricius Tiberius (582602), intervalul de batere propus fiind 583/584. Avem astfel, indirect, un indiciu important care confirmă datarea tiparului în secolele VI-VII' ${ }^{12}$.

\footnotetext{
6 Nestor și Nicolaescu-Plopșor 1938, Taf. 7. O contextualizare și o descriere detaliată în Oanță-Marghitu R. 2018a, 167-169 și Oanță-Marghitu R. 2018, 665-667.

Măgureanu și Ciupercă 2007, cat. 2, 302-303, fig. 5, 10. Am păstrat pentru tiparele de la Budureasca numerele de catalog stabilite în această publicație.

8 Măgureanu și Ciupercă 2007, cat. 9, 304-305, fig. 5, 10.

9 Puține, aşa cum sunt, accesoriile metalice datate în secolele VI-VII p.Chr. sunt de cele mai multe ori publicate prin intermediul desenelor și, în cele mai multe cazuri, lipsesc atât fotografiile de bună calitate cât și informațiile detaliate despre tehnica de realizare a acestora. Situația este ilustrativă, de exemplu, în cazul cerceilor cu pandantiv stelat (Comșa 1971; Teodor 1995). Unii dintre aceștia, în structura cărora am putea bănui că ar fi putut fi integrate componente obținute cu ajutorul tiparului în discuție, sunt cunoscuți doar prin intermediul desenelor.

10 Despre cerceii cu pandantiv piramidal: Bálint 1993, 217-218, 256-259 liste, 257 hartă (tipul Szegvár - regăsit și în spațiul nord şi est-pontic); Ormándy 1995 (tipul Szegvár - 154-155, fig. 1/7-10).

11 Dumanov 2012, 411, fig. 7 (nu ne este foarte clar dacă punctele din desen reprezintă mici excavații care pe piesa turnată s-ar fi transformat în granule).

12 Garam 1992, 139-140, Taf. 15/8.
} 
Chiar dacă asemănările evidențiate nu sunt perfecte, piesele la care ne-am raportat fiind cu mult mai elaborate, trebuie ținut cont și de faptul că acestea - fibula și cerceii din tezaurul de la Coșovenii de Jos sau cerceii de tip Szegvár și Deszk - sunt podoabe lucrate din metale prețioase, argint și aur. Așa cum vom încerca să demonstrăm mai jos, atât tiparul studiat în acest articol cât și cele comparabile, nu erau folosite pentru modelarea aurului sau argintului. Chiar dacă modelul de referință rămâne același, schimbarea metalului de bază implica modificarea tehnologiei de producție. Corelat se modifica şi aspectul general şi/sau dimensiunile artefactelor. Atunci când obiectele din metale prețioase erau transpuse în metale mai puțin nobile puteau suferi unele modificări, adesea în sensul simplificării sau micşorării dimensiunilor. Discuția rămâne oricum deschisă.

Toate cele șase mici elemente - sau chiar șapte, dacă îl luăm în consideraţie și pe e - realizabile cu ajutorul acestui tipar ar putea fi văzute funcționând, în ciuda dimensiunilor reduse, și ca piese de sine stătătoare. Un detaliu importat este faptul că, fiecare în felul său, puteau fi suspendate sau înşirate având ori o verigă de prindere (b1, c, e şi f) ori fiind chiar un fel de verigi (a, b2, d). Folosite ca mărgele sau pandantive, ele ar fi fost înşirate sau integrate în diferite moduri în structura unor coliere sau a unor podoabe mai elaborate destinate împodobirii gâtului și/sau pieptului. Dacă ne raportăm însă la zona de proveniență a tiparului, valabilitatea acestei propuneri nu este însă verificată de existența unor artefacte comparabile în repertoriul de forme contemporan. Ar trebuit ținut însă cont de faptul că recuperarea din săpătura arheologică a unor piese atât de mărunte, realizate din plumb sau staniu, așa cum vom încerca să demonstrăm mai jos, ar fi fost foarte dificilă în contextul în care tamisarea nu reprezintă și nu a reprezentat o cutumă în cercetarea arheologică a siturilor datate în secolele VI-VII. Fiind piese mărunte, nu este exclusă nici oxidarea puternică și/sau distrugerea în pământ. Pe de altă parte, elementele folosite pentru împodobirea capului, gâtului și pieptului, așa cum sugerează, de exemplu, imaginea conturată de inventarele funerare din necropola nr. 3 de la Bratei, erau foarte diverse, fiind combinate diferite forme de pandantive și de mărgele. Ilustrativ, în context, este inventarul mormântului nr. 76 în care s-au păstrat mai multe elemente granulate, deteriorate și incomplet recuperate, integrate probabil printre podoabele gâtului. Piesele sunt metalice, dar corelat nu se menționează nici bronzul și nici $\operatorname{argintul}^{13}$. În același context am putea adăuga și faptul că, privite de sus, mărgele de sticlă multicolore, ornamentate cu „ochi”"14 - o prezență comună în epocă în mediul avar - aveau un contur asemănător cu cel al verigilor anturate de granule (a, b2, c, d) obținute cu tiparul de la București-Băneasa, Str. Gârlei.

Urmele de ardere de pe reversul tiparului sugerează faptul că și această faţă avea un rol bine determinat în procesul tehnologic, fiind folosită în pereche cu un alt tipar pe a cărui suprafaţă fuseseră sculptate alte forme de turnare. Zgârieturile, foarte vizibile, sugerează o intenție de prelucrare și a acestei fețe, proiect nematerializat însă din cine știe ce motiv. Judecând după traseul zgârieturilor, acestea s-ar fi putut transforma în canale mai bine definite, destinate probabil obținerii unor bare de mici dimensiuni, sub forma unor lingouri, elemente prelucrate ulterior prin ciocănire sau alte tehnici. Un aspect asemănător se observă pe reversul tiparului de la București-Soldat Ghivan, o așezare contemporană amplasată tot pe malul râului Colentina, cu aproximație 7-8 km în aval, cam la o oră și jumătate sau două de mers pe jos ${ }^{15}$. Un alt tipar cu un aspect asemănător, fragmentar însă, face parte din grupul celor 64 de tipare descoperite în bordeiul numărul 36 de la Bernašivka, din Transnistria ${ }^{16}$. Și în acest caz se disting capetele mai multor canale distribuite relativ paralel dar destul de dezordonat.

\section{Tipare de turnare din secolele VI-VII}

Dacă trecem în revistă tiparele cunoscute, dintre piesele comparabile se evidențiază, aşa cum am menționat anterior, aspectul unuia dintre cele descoperite la Budureasca cat. $2\left(\mathrm{Pl}\right.$. IV/2) ${ }^{17}$. Asemănarea existentă, o parte dintre elemente corespunzând atât ca număr cât și ca aspect, susține ideea sculptării pe un tipar a tuturor elementelor necesare pentru obținerea sau ornamentarea unui anumit obiect. Alături de asocierea formală dintre tiparul de la Budureasca cat. 2 și cel de la București-Băneasa, Str. Gârlei, ideea este susținută și de existența altor perechi de tipare pe care sunt sculptate seturi de forme asemănătoare: Argamum (Jurilovca) - Budureasca cat. 9 - Budureasca cat. 10 - Cristuru Secuiesc (grupaje de $\approx 9$ granule şi un mic canal semicircular), Argamum (Jurilovca) - Cristuru Secuiesc (granule dispuse în cruce), Budureasca cat. 10 - Străulești-Măicănești (perechi de granule) ${ }^{18}$. În ciuda acestor asemănări observate pe tipare, ar rămâne însă de identificat, mai exact, artefactele în structura cărora putem recunoaște respectivele elemente ${ }^{19}$.

\footnotetext{
13 Bârzu 2010, 191, Taf.14/G.76/2c,d,e și 3f; despre podoabele destinate împodobirii capului și gâtului: Bârzu 2010, 72-94, Abb. 46.

14 Bârzu 2010, 83-92 (tip 14f.01.11); ilustrativ: Taf. 87/G237 (centru jos), Taf. 90/G248 (centru jos).

15 Teodorescu 1972, 81, fig. 3/1; fotografii mai recente:

http://clasate.cimec.ro/detaliu.asp?tit=Tipar\&k=7906E9F1BD734436AF9BBFD2C7E9FED3 (consultat 27.11.2020)

16 Tănase 2010, Pl. LXXVIII/8.

17 Măgureanu și Ciupercă 2007, 302-303, fig. 5, 10.

18 Ilustrativ Oanţă-Marghitu R. 2006, pl. 3. Discuția reluată în Măgureanu 2008, 177-179.

19 Acest obiectiv s-ar putea atinge, în mod real, doar prin studierea atentă și simultană a tiparelor și artefactelor în structura
} 
De-a lungul timpului, în literatura de specialitate din România, tema prelucrării metalelor neferoase în vederea obținerii unor podoabe sau accesorii vestimentare a fost în mod repetat reluată în mai multe publicații ${ }^{20}$. Raportat la diferitele categorii de artefacte puse în legătură cu această activitate - creuzete, linguri de turnare sau mic instrumentar metalic - tiparele folosite pentru turnarea metalelor s-au evidențiat ca o categorie aparte, relativ simplu de identificat, particularizate prin existența pâlniilor de turnare (culee) și uneori prin cea a unor canale suplimentare, mai subțiri, de ventilație. Acestea reprezintă o categorie distinctă, diferită de tiparele într-o anumită măsură asemănătoare dar lipsite de canale de turnare, piese destinate deformării plastice a foilor metalice sau obținerii unor modele de ceară care ar fi fost ulterior transformate în tipare din bronz, patrițe, peste care s-ar fi putut presa foile metalice ${ }^{21}$.

Referitor la distribuția spațială a tiparelor de turnare relativ contemporane se poate observa concentrarea mai multor descoperiri pe teritoriul orașului București, situație datorată în parte și faptului că, de-a lungul timpului, această zonă a fost mai intens studiată din punct de vedere arheologic ${ }^{22}$. O conjunctură comparabilă se poate observa și la Budureasca unde, de-a lungul unei cercetări microzonale, s-au descoperit mai multe artefacte și ansambluri care pot fi corelate cu prelucrarea locală a metalelor neferoase ${ }^{23}$. Astfel, într-un context s-au grupat mai multe tipare, iar în alte puncte au fost identificate atât tipare cât și artefacte încadrate în categoria micului instrumentar de orfevrărie și deșeuri metalice ${ }^{24}$. Acestora li se adaugă şi alte exemplare, multe dintre ele din Moldova, descoperite - la fel ca cele de la Budureasca sau din București - cu ocazia unor cercetări arheologice sistematice şi de amploare ale siturilor din care provin ${ }^{25}$.

cărora ar putea intra elemente obținute prin utilizarea respectivelor tipare. Așa cum am menționat anterior, desenele artefactelor pot oferi eventual doar indicii asupra pieselor care ar trebui investigate în detaliu. În context, arheologia experimentală ar oferi, la rândul său, informații foarte importante, verificând sau infirmând propunerile bazate doar pe aspectul și caracteristicile fizice ale tiparului.

20 Teodorescu 1972; Teodor 1996; Teodor 2005; Măgureanu și Ciupercă 2007; Ciupercă și Măgureanu 2009; Tănase 2010; Gândilă 2018, 69-76; Tănase 2021, în curs de apariție.

21 Problematica acestei categorii de tipare este discutată în Szmoniewski 2002 sau Măgureanu 2008, 174-177. Aceleași artefacte fuseseră anterior considerate ,tipare pentru turnat calapoade-modele” (Teodorescu 1972, 91). Distincția între tiparele de turnare și cele sculptate tot în piatră dar lipsite de pâlnii, canale de turnare și canale de ventilație nu a fost întotdeauna în mod clar marcată. Referitor la aceste tipare, nu poate fi însă exclusă nici turnarea directă a unor aliaje de staniu și/sau plumb, cu puncte de topire scăzute, cantitatea relativ redusă de metal permițând o solidificare rapidă şi apoi extragerea elementelor. Pot fi menționate, în context, și exemplele etnografice sau discuțiile referitoare la corecta interpretare a unora dintre aceste tipare pentru care s-a propus și o datarea mult mai târzie, în secolele XVIII-XIX (Anton, Enea și Vasilache 2020; Diaconu 2015).

22 București-Soldat Ghivan (tipar cu două fețe - verigi diverse, granule, sârme/bare subțiri - Teodorescu 1972, 94, nr. 6a, fig. 3/1), București-Dămăroaia (verigă/cataramă ? - Teodorescu 1972, 93, nr. 3b, fig. 2/5), Străulești-Măicănești (granule, perechi de granule - Teodorescu 1972, 95, nr. 8a, fig. 5/4), Străulești-Lunca (cruciuliță - Teodorescu 1972, 94, nr. 7a, fig. 3/6).

23 Teodorescu 1972; Măgureanu și Ciupercă 2007.

24 În particular complexul (groapa) G.T 1967 din situl de la Budureasca 4 „Puțul tătarului” în care au fost descoperite patru tipare: Măgureanu și Ciupercă 2007, 293, fig. 4, 5, 6, 10. Mic instrumentar și deşeuri metalice: Teodorescu 1972, fig. 6/1-3, 5-7, 11-12.

${ }_{25}$ Botoșana, jud. Suceava - O așezare datată de la sfârșitul secolului al V-lea până la începutul secolului al VII-lea în care din 1962 până în 1974 au fost cercetate 31 de locuințe. Tipare s-au descoperit în locuința 25 (tipar fragmentar pentru două granule) și locuința 27 (tipar pentru o cruciuliță; pe revers prelucrarea nu a fost finalizată fiind realizat doar un canal de ventilație? pe traseul căruia sunt săpate trei cavități pentru granule) - Teodor 1984, 39-40, fig. 19/6 și 20/3 (L25); 40-41, fig. 20/1 și 21/1 (L27); Teodor 2005, 163, cat. 1, fig. 3/2; fig. 8/5. Cristuru Secuiesc, jud. Harghita - O aşezare care se poate data în secolele VI-VIII, acolo fiind cercetate opt bordeie cu pietrar. Tiparul, rectangular, descoperit lângă vatra locuinței nr. 4 alături de câteva fragmente ceramice, are câte o pâlnie de turnare pe fiecare dintre laturile înguste, canalele desprinse din acestea conducând într-o parte către două grupaje de granule şi în cealaltă către trei grupaje de granule, dispuse în cruce şi asociate cu o verigă Székely 1971, 357-358. Davideni, jud. Neamt - O așezare în care, de-a lungul a 22 de campanii (1970-1979 și 1986-1997) au fost cercetate 75 de locuințe și alte construcții anexe. Au fost descoperite trei tipare: unul (T1), din care s-a păstrat doar o parte folosită pentru obținerea unor granule, a fost descoperit în nivelul corespunzător așezării din secolele V-VII (secțiunea I/1970) și a fost datat de autorul cercetării arheologice în ultima parte a secolului al V-lea sau prima jumătate a secolului al VI-lea (pe baza unor urme de finisaj, I. Mitrea a considerat piesa ca fiind tipar pentru turnarea unor cruciulițe; reconstituirea sugerată reprezintă doar o propunere, excavațiile destinate obținerii granulelor fiind singurele care se pot identifica în mod cert); al doilea (T2), descoperit în locuința 33, este tot fragmentar, pe una dintre fețe se pot observa trei excavații și o pâlnie de turnare nefinalizată; al treilea tipar (T3), descoperit în locuința 36, este tot fragmentar, pe suprafața sa putându-se observa doar mai multe canale de turnare - Mitrea 2001, 134-135, 325, fig. 65/1 (T1), 65/5 (T2), 65/4 (T3). Gura Idrici, jud. Vaslui - Tiparul a fost descoperit în apropierea unui bordei deranjat, B1, datat de către cei care 1-au cercetat între mijlocul secolului al VIII-lea și mijlocul secolului al IX-lea, în stratul de cultură în care a fost descoperit întâlnindu-se şi numeroase fragmente ceramice care se puteau data în intervalul secolelor IV-VI. Pe tipar, ilustrat doar printr-un desen, se pot observa mai multe canale de turnare, fiecare conducând către o pereche de granule - Coman, Alaiba 1980, 453-454, fig. 5/1. Selişte, raion Orhei, Republica Moldova - Cercetări sistematice din anii 1970-1971. A fost descoperit un tipar în locuința L1. Piesa era probabil folosită pentru obținerea 
Dacă privim în ansamblu diversitatea formelor sculptate pe tiparele trecute în revistă putem observa, ca o caracteristică generală, faptul că predomină contururile unor elemente de mici dimensiuni care erau probabil folosite ulterior pentru asamblarea unor piese mai elaborate. Singurele exceptii notabile le reprezintă tiparele destinate turnării cruciulițelor ${ }^{26}$ și o altă piesă, singulară, folosită probabil pentru obținerea unor aplice ${ }^{27}$. Spre deosebire de situaţia particulară de la nord de Dunăre, pe tiparele relativ contemporane, datate în intervalul secolelor VIVII și descoperite la sud de Dunăre, formele accesoriilor vestimentare sau ale podoabelor care puteau fi obținute cu ajutorul acestora se recunosc mai ușor ${ }^{28}$. Artefacte de mici dimensiuni care, lipsite de informațiile oferite de privilegiul descoperirii într-un context arheologic bine definit, nu oferă toate informațiile necesare unei corecte încadrări cronologice, tiparele asemănătoare celui de la București-Băneasa, Str. Gârlei par să nu fie consemnate în spațiul sud-dunărean, în contexte romano-bizantine bine definite. Nu putem ști însă dacă acest lucru se datorează faptului că au fost trecute cu vederea fiind considerate, poate, lipsite de importanță sau pur şi simplu nu există ${ }^{29}$. Important de evidenţiat este faptul că tiparele de turnare descoperite la sud de Dunăre, prin aspectul şi modul de întrebuinţare, se încadrează mai bine în tradiția antică de prelucrare a metalelor neferoase. Cele de la nord de Dunăre, prin elementele de mici dimensiuni care duc cu gândul la aspectul artefactelor granulate, sunt atipice în context și reprezintă, pentru acest spațiu, o categorie de piese caracteristică doar secolelor VI-VII p.Chr.

\section{Ce metale se turnau?}

Turnarea în tipare este foarte bine atestată și în alte epoci istorice cunoscându-se diferite forme de tipare bivalve din piatră. Important de observat este faptul că, de fiecare dată, piesele obținute aveau dimensiuni relativ mari comparativ cu bavurile care rămâneau în urma procesului de turnare, manipularea acestora nefiind îngreunată de proporțiile miniaturale. Regula aceasta nu se verifică însă și în cazul tiparelor în discuție.

Tiparele asemănătoare celui de la București-Băneasa, Str. Gârlei au fost în mod constant încadrate în micul instrumentar al orfevrilor care lucrau podoabe sau mici accesorii vestimentare. Ar trebui totuși evidențiat faptul că, din perspectiva tradiției antice clasice, prelucrarea metalelor prețioase, a aurului și argintului, nu include în instrumentarul dedicat și acest tip de tipare, destinate obținerii unor elemente de mici dimensiuni. Porozitatea rocilor folosite și tocmai dimensiunile reduse ale elementelor obținute prin folosirea acestor tipare nu le recomandă pentru turnarea metalelor prețioase, aur sau argint. Foarte maleabil și ductil, aurul permite nenumărate variante de deformări plastice, punctul de pornire putând fi chiar și un lingou cu o formă iniţială nedeterminată. Ulterior, lingourile din aur sau argint puteau fi transformate cu mare ușurință în foi, bare sau sârme cu diferite grosimi sau diametre, podoabele fiind construite uneori prin folosirea unor suduri punctuale succesive sau alteori doar prin înnodarea sau răsucirea sârmelor ${ }^{30}$. Verigile sau granulele nu se obțineau prin turnare. Pentru obținerea granulelor, în funcție de mărimea acestora, s-au identificat și s-au propus mai multe soluții ${ }^{31}$. Chiar și pentru granulele mai mari, turnarea în tipar de piatră este puțin probabilă în contextul în care cantitatea de metal pierdută prin porozitatea

unor granule, cavitățile fiind dispuse liniar, în grupe de câte trei sau două, la capetele fiecărui canal de turnare - Teodor 2005, fig. 2/3. Ștefan cel Mare, jud. Bacău - O aşezare datată în secolele VI-VII, suprapusă de un sat medieval. Situl a fost cercetat cu intermitențe între 1971 și 1990, fiind descoperite peste 18 locuințe. Tiparul a fost descoperit în 1977 în locuința L2 împreună cu ceramică caracteristică secolelor VI-VII. Piesa este cunoscută prin intermediul unui desen: pe una dintre fețe se pot distinge contururile unor verigi? și/sau granule?, nefiind foarte clar dacă reliefurile sugerate marchează spărturi în piatră sau pâlnii de turnare; pe cealaltă față, transversal, sunt marcate trei canale de ventilație pe traseul cărora sunt săpate câte două cavități pentru granule; nici de această dată nu este foarte clar dacă există sau nu pâlnii de turnare (Mitrea 1980, 108, P1. XLVI/1; Teodor 2005, fig. 2/1).

26 Olteni, jud. Teleorman (Preda 1967); București-Străulești (Constantiniu 1966, 673-675); Botoșana, jud. Suceava (Teodor 1978, 20-21, 164, fig. 5/5; Teodor 1981, 105, fig. 13/1); Sânmiclăuş, jud. Alba (Dănilă 1982, 735-736, pl. 3; Gudea și Ghiurco 1988, 200, pl. 34).

27 Traian, jud. Bacău (Teodor 2005, 165, cat. 25, fig. 8/6).

28 Dumanov 2012; Brokalakis 2012. Un atelier datat în secolul al VII-lea se cunoaște și în Thessalonic, acolo fiind descoperite numeroase tipare de piatră și lut pentru piese sferice, verigi, diferite forme de amulete, rotunde, rectangulare, stelate, piramidale (Antonaras 2016, 158-150, cat. 50). Despre existența unor ateliere la Justiniana Prima (Caričin Grad), Ivanišević 2018.

29 Diferența dintre peisajul arheologic de la sud și de la nord de Dunăre a condus, implicit, și la unele diferențe de abordare a cercetării arheologice. Artefacte care la sud de Dunăre ar putea fi chiar trecute cu vederea, la nord de Dunăre pot deveni piese importante, studiate în detaliu, conferite uneori cu o importanță aparte prin prisma originii lor în mod real sau presupus bizantine. Astfel, la sud de Dunăre, deşi se cunosc numeroase tipare pentru obiecte bine definite, nu există, aşa cum am evidențiat, exemplare comparabile cu piesa care face obiectul acestei investigații sau cu tiparele destinate obținerii granulelor. Raportat la domeniul prelucrării metalelor neferoase și al perioadei secolelor VI-VII, în colecțiile muzeelor se păstrează diferite tipare, exemplarele publicate fiind destinate obținerii unor artefacte ce pot fi relativ ușor recunoscute în cultura materială contemporană, pe o parte importantă dintre acestea putându-se recunoaște și semnul crucii.

30 O prezentare condensată a diferitelor tehnici folosite în modelarea aurului și a argintului: Higgins 1980, 11-30.

31 Carroll 1974, 34; Wolters 1981; de Callataÿ 1983; Duczko 1985; Roth 1986, 55-57; Schwarcz şi Varga 2010. 
pietrei și pe canalele de turnare ar fi fost destul de mare raportat la elementul obținut. Prin turnare se obțineau însă, de exemplu, unele inele ${ }^{32}$ sau catarame și diferite elemente de centură ${ }^{33}$ fiind însă vorba de fiecare dată de piese mai masive.

Granulația a reprezentat, de-a lungul timpului, o tehnică apreciată și iubită de ornamentare a podoabelor. Chiar dacă nu mai regăsim o granulație foarte fină, asemănătoare cu cea întâlnită pe podoabele etrusce sau elenistice, aceasta se poate observa în mod constant și în orfevrăria romană. Se foloseau granule cu diametrul în jur de 1 mm, sau chiar mai mari, rolul lor decorativ fiind uneori dublat și de unul funcțional, consolidând punctele de sudură, integrate în structura de rezistență a pieselor. În mod asemănător, în secolele VI-VII granulaţia a fost mai mult folosită pentru a evidenția anumite zone din compoziția pieselor mai elaborate, adesea anturând montura în care erau fixate diferite geme. În Imperiul Bizantin poate fi astfel întâlnită în compoziția cerceilor sau a inelelor, pe podoabele gâtului sau prezentă în ornamentația cruciulițelor pandantiv. Granulația apare chiar și pe unele componente ale garniturilor de centură compozite (prevăzute cu curele secundare), piese regăsite sporadic atât în spațiul nord-pontic cât și la sud de Dunăre sau în zona controlată de avari a Dunării mijlociii ${ }^{34}$. Deși toate piesele la care s-a făcut referire în acest paragraf sunt din metale prețioase, trebuie evidențiată totuși persistența în timp a acestei tehnici ornamentale, efectul vizual produs de artefactele decorate astfel fiind ca urmare familiar oamenilor timpului.

Chiar dacă se face abstracție de pierderile importante de materie primă pe care le-ar implica folosirea tiparelor de piatră pentru turnarea metalelor prețioase, acestea tot nu ar fi rezistat la temperaturile înalte ale aurului sau argintului topit, $1064^{\circ} \mathrm{C}(\mathrm{Au})$ sau $962^{\circ} \mathrm{C}(\mathrm{Ag})$. Bronzul, la rândul său, în funcție de compoziția aliajului, are puncte de topire comparabile $\left(\approx 880-1050^{\circ} \mathrm{C}\right)$. Pornindu-se de la observația că piatra se deteriora atunci când era încălzită la temperaturi atât de mari și că nici nu putea să reziste la încălziri repetate, a rămas posibilitatea folosirii tiparelor din piatră pentru turnarea unor aliaje cu temperaturi de topire mult mai mici, pe bază de staniu și plumb ${ }^{35}$. De la Budureasca de exemplu, fără a se oferi detalii referitoare la contextul în care au fost descoperite, alături de tipare și micul instrumentar pus în legătură cu orfevrăria, au fost publicate și două deșeuri de plumb şi un pandantiv din plumb $^{36}$. Ar trebui menționat și faptul că, descoperit în săpătura arheologică, plumbul este adesea acoperit cu un sediment calcaros și, dacă artefactul nu are o formă aparte, bine definită, în cazul nostru putând fi vorba de mici lingouri informe sau de deșeuri de turnare, poate fi confundat cu uşurință cu o piatră. La temperaturi reduse, sub $13^{\circ} \mathrm{C}$, staniul alb, argintiu, sau aliajele cu un conținut mare de staniu se pot acoperi cu un strat de pulbere cenuşie sau se pot transforma în totalitate în praf. Ca urmare, conservarea în sol a obiectelor realizate din aliaje cu un conţinut ridicat de staniu este de cele mai multe ori problematică.

Propunerea enunțată anterior este confirmată și de rezultatul analizelor realizate prin fluorescență de raze X. Măsurătorile realizate asupra reziduurilor metalice păstrate în cele două găuri de ghidaj au evidenţiat un aliaj de staniu și plumb $(95,28 \% \mathrm{Sn}, 3,81 \% \mathrm{~Pb}$ și $0,47 \% \mathrm{Cu})$. Urme de staniu și de plumb au fost identificate și în zona înnegrită a pâlniei de turnare A. Atât analizele realizate direct pe suprafața dreaptă a pietrei cât și cele de pe grupajele de la capetele canalelor a, b1 și c, nu au evidenţiat staniul dar au surprins însă uşoare urme de plumb ${ }^{37}$. Rocile în care erau sculptate tiparele erau astfel alese încât să permită îndepărtarea facilă a formelor metalice după solidificare $^{38}$. În context, se poate observa totuşi relativa aderență a elementelor în zonele uşor înnegrite de fum.

Prin prisma rezultatului investigațiilor și ținând cont de aspectul de astăzi al tiparului, cu fragmente metalice blocate în găurile de ghidaj - un aliaj pe bază de staniu - am putea bănui și o anume inabilitate tehnologică. Pentru a putea refolosi de mai multe ori setul de tipare suprapuse, aliajul din care erau realizate barele introduse prin

\footnotetext{
32 De exemplu, pentru o altă perioadă istorică însă: Konstantinidi-Syvridi, Kontaki 2009.

33 Ivanišević 2018, fig. 1/1-3, 3/1,3-4, 5/1-2.

34 Diferite trimiteri pe această temă, granulația în spațiul de influenţă bizantină în sec. VI-VII, în Oanță-Marghitu R. 2006, 357-359. Sugestiv în context este micul tezaur de la Histria: o pereche de cercei, două inele și două cruci-pandantiv (Popescu 1994, 374-376; o contextualizare și ilustrație actuală în Oanță-Marghitu R. 2018a, 169 și Oanță-Marghitu R. 2018, 649-651).

35 Zerres 2016, 123-125. În context este în mod frecvent citat un articol la care, din păcate, nu am avut acces în totalitate: H. Drescher, Untersuchungen und Versuche zum Blei- und Zinnguß in Formen aus Stein, Lehm, Holz, Geweih und Metall. Ein Beitrag zur mittelalterlichen Gießtechnik von Kleingerät, Frühmittelalterliche Studien 12, 1978, 84-115. Ideea folosirii tiparelor de turnare de piatră, de la nord de Dunăre, în asociere cu aliajele de staniu și/sau plumb a fost enunțată, pornind de la concluziile articolului menționat (Drescher 1978), și în Fiedler 2010, 239.

36 Teodorescu 1972, fig. 6/8 (un pandantiv pseudogranulat, turnat din plumb), 6/11-12 (bucăți informe, deșeuri de plumb). Piesele provin din situl Budureasca 4; groapa G.T./65 în care s-au descoperit patru tipare de turnare aparține aceluiași sit. Din publicații nu rezultă care este relația dintre pandantivul de plumb și deșeurile de plumb, pe de o parte, și tipare, pe de altă parte. 37 Mulțumim doamnei Dr. Zizi Baltă pentru investigarea tiparului prin fluorescență de raze X.

38 Într-un set de tipare descoperit în 1962 la Rüsselsheim-Haßloch (Germania) a fost turnat un aliaj de bismut și plumb în anul 1970. Investigațiile de laborator realizate în anul 2016 asupra celor două valve ale tiparului nu au evidenţiat în mod clar urmele aliajului turnat în 1970 (Zerres 2016, 123-125).
} 
găurile de ghidaj ar fi trebuit să aibă un punct de topire mai ridicat decât cel al aliajului care urma să fie turnat. În cazul tiparului de la București-Băneasa, Str. Gârlei, acestea au avut un punct de topire apropiat de cel al metalului prelucrat, ca urmare s-au blocat se pare în găurile de ghidaj, fapt care a condus apoi și la ruperea acestora. Practic, ciobirea tiparului în aceste zone și ruperea barelor ar sugera faptul că procesul tehnologic nu era chiar în totalitate controlat sau înţeles.

În discuțiile legate de funcționalitatea tiparelor de piatră apare în mod repetat ideea folosirii acestora pentru obținerea modelelor din ceară ale pieselor care ar fi fost ulterior turnate prin metoda cerii pierdute ${ }^{39}$. Sugestia poate fi acceptată în cazul pieselor cu un volum mai mare, această soluție putând reduce, în situațiile în care se realizau seturi de mai multe piese asemănătoare, timpul necesar sculptării fiecărui model în parte ${ }^{40}$. Totuși, soluția își pierde valabilitatea atunci când este vorba de piese de foarte mici dimensiuni. Granulele nu se obțineau prin metoda cerii pierdute. Singura opțiune acceptabilă pare să rămână astfel cea a aliajelor cu temperaturi de topire reduse, pe bază de plumb și/sau staniu. Deși tiparele de turnare caracterizate prin prezența negativelor unor elemente pseudogranulate de mici dimensiuni reprezintă o particularitate a perioadei secolelor VI-VII, folosirea unor tipare de piatră comparabile ca aspect pentru turnarea unor aliaje cu puncte de topire joase este destul de bine documentată și în alte perioade istorice ${ }^{41}$.

În Imperiul Roman plumbul a reprezentat un metal comun și cu întrebuințări diverse, adesea folosit și pentru realizarea unor artefacte relativ mici, cum ar fi ramele oglinzilor, statuetele destinate depunerilor votive de pe lângă temple sau realizării unei mari diversități de amulete ${ }^{42}$. Metale ieftine și ușor de prelucrat, plumbul și staniul au reprezentat se pare o alternativă accesibilă a artefactelor din metale prețioase sau chiar bronz. Contururile atent sculptate pe piatră și versatilitatea metalelor folosite permiteau obținerea unor profiluri și a unor efecte regăsite frecvent pe piesele din metale prețioase. Dorința de a reproduce granulele se observă atât pe tiparul în jurul căruia este construit acest articol cât și pe un alt tipar din Heerlen (Olanda), destinat obținerii unor amulete și datat în a doua jumătate a secolului al III-lea prin prisma materialului alături de care a fost descoperit, terra sigillata și o monedă emisă în anul $252^{43}$. Aceleași granule se recunosc și pe o cruciuliță pandantiv, turnată în plumb, găsită pe malul Dunării (Sucidava-Izvoarele, jud. Constanța) și datată foarte probabil în secolul al VI-lea ${ }^{44}$.

Dacă ne raportăm la podoabele și accesoriile vestimentare metalice datate în secolele VI-VII, piesele de staniu și/ sau plumb în spațiul de la nord de Dunăre par să fie aproape inexistente ${ }^{45}$. Suntem în situația în care, deși cunoaştem

\footnotetext{
39 Despre această metodă: Hunt 1980.

40 De exemplu, piesele menționate la n. 32 și 33.

${ }^{41}$ În Magdeburg (Germania) au fost descoperite peste 500 de tipare destinate turnării aliajelor de staniu și/sau plumb, ansamblul datându-se în secolul al XIII-lea (Berger 2006; mai nou Berger, Ditmar-Trauth şi Wunderlich 2020). Alte forme de turnare datate în secolele XIII-XIV, descoperite în Zerbst, în apropiere de Magdeburg: Berger și Malliaris 2014. Diferite tipare de turnare descoperite pe teritoriul Bulgariei și datate în secolele IX-XIV: Doncheva 2015.

42 O trecere în revistă a domeniilor în care era utilizat plumbul în provincia Dacia în Benea 2009. Obiceiul de a depune mici statuete reprezentând diferite zeități este răspândit în Imperiul Roman. Fără a trece în revistă fenomenul, menționăm doar un exemplu: cu ocazia cercetării arheologice a templului de la Klosterfrauenbichl (Austria) în Noricum, au fost descoperite în jur de 550 de fragmente, înălțimea maximă a statuetelor nefiind mai mare de 6,5-7,5 cm (Grabherr și Kainrath 2019).

43 Schmitz 1993, 48-49. Detalii asemănătoare se observă și pe un alt tipar, prezentat în acelaşi articol, piesă care are însă un context de descoperire mai puțin clar (p. 47). Interesant de observat este asemănarea dintre conturul destinat obținerii unor amulete de tip lunula și cel de pe tiparul Budureasca cat. 2 (Pl. IV/2), în formă de ,potcoavă”, aflat la capătul canalului de turnare d (Schmitz 1993, 47/pozitiv, fig. 3, în centru, 49/pozitiv, fig. 6/1 pe de o parte și, pe de altă parte, Măgureanu și Ciupercă 2007, fig. 5/cat. 2/d). Alte tipare destinate turnării unor aliaje ale staniului şi/sau plumbului au fost descoperite și la Xanten (Linsen 2006).

44 Este vorba de cruce latină cu brațele ușor evazate (Culică 1969, cat. 20, fig. 1/3b).

45 Printre aşa numitele ,antichități slave” există însă şi podoabe compuse din elemente de mici dimensiuni, realizate din aliaje de staniu și/sau plumb, unele dintre acestea având forme asemănătoare celor care se pot obține cu tipare asemănătoare celor de la București-Băneasa, Str. Gârlei sau Budureasca, cat. 2, 9, 10 (Rodnikova 2011, 242-243, fig. 1/20-24). De exemplu, din tezaurul de „meșteșugar” de la Veli Budki, din nord-estul Ucrainei, în care alături de piese finite au fost depuse și semifabricate sau artefacte fragmentare, fac parte și peste 1200 de mici elemente care puteau fi cusute pe veșminte (Gorjunova 1992, 135/ tabelul cu compoziția aliajelor și 139/fig. 2/1-4).

De asemenea, chiar dacă este vorba de artefacte de sine stătătoare și cu dimensiuni mai mari decât micile elemente obținute prin folosirea tiparului de la București Băneasa, Str. Gârlei, se poate totuşi circumscrie un grup destul de amplu de piese realizate din aliaje cu un conținut mare de staniu și/sau plumb și datate chiar în secolele VI-VII. Cu ocazia republicării și discutării așa numitului tezaur de la Velestino (Tesalia, Grecia) sunt trecute în revistă mai multe descoperiri din Europa Centrală și Răsăriteană, până către Munții Ural, ansambluri din care fac parte și piese metalice realizate din astfel de aliaje (Curta și Szmoniewski 2019, 163-165). Dintre artefactele descoperite pe teritoriul României putem menționa o cruciuliță de plumb descoperită în așezarea de la Traian-Săbăoani, jud. Neamț, în locuința L9, datarea pentru piesă și contextul din care provine fiind secolele VI-VII (Hânceanu 2015, 124-125, pl. 3). La Sânpaul (jud. Cluj) a fost cercetat de curând un grup de trei morminte datate în secolul al V-lea; într-un mormânt s-au descoperit trei pandantive de plumb, nu cu mult mai mari decât piesele obținute
} 
un număr important de tipare de turnare folosite pentru obținerea unor piese din aliaje de staniu şi/sau plumb, în repertoriul arheologic nu existe artefacte care ar fi putut fi obținute cu ajutorul acestora. Un fenomen comparabil a fost evidențiat și în alte contexte, chiar și în raport cu setul atât de numeros de tipare de la Bernašivka ${ }^{46}$. Așa cum am subliniat anterior, obiectele realizate din aliaje de staniu pot să nu fie foarte rezistente în timp şi conservarea lor în sol este extrem de problematică. Pe de altă parte, aceste metale nu erau doar ușor de prelucrat ci erau și foarte uşor de recuperat și de refolosit. În plus, în contextul în care nu a existat încă nici o preocupare specială și constantă de identificare a aliajelor din care au fost realizate aceste piese metalice, putem bănui că printre cele care nu sunt nici din aur și nici din argint sau bronz se ascund și astfel de aliaje, cu puncte de topire scăzute. Doar ca o propunere, dintre piesele despre care se spune că sunt realizate din potin (un aliaj de cupru, staniu și plumb în cantități variabile), unele ar putea intra în această categorie ${ }^{47}$. Odată acceptată și conștientizată folosirea aliajelor cu puncte scăzute de topire ca materii prime pentru realizarea unor podoabe și/sau a unor accesorii vestimentare, am putea descoperi că numărul artefactelor care sunt lucrate din aceste metale este în realitate mai mare. De asemenea, un efort constant în sensul identificării mai exacte a compoziției aliajelor ar conduce, în timp, atât la o mai bună definire sau caracterizare a acestui grup, cât și la extinderea considerabilă a numărului de piese care îl compun.

\section{Concluzii}

Un detaliu important, dacă ne raportăm la intervalul secolelor VI-VII în spațiul extra-carpatic, este şi raritatea extremă a pieselor din metale prețioase. Absența podoabelor din metale prețioase nu echivalează însă cu absența podoabelor în sine. Acestea, realizate chiar și din metale sau materiale mai puțin nobile, se raportau din punct de vedere vizual la aceleași modele elaborate, adesea ornamentate cu granulație, lucrate din metale prețioase. Cerceii, în particular cei cu pandantive stelate sau piramidale, reprezintă o posibilă categorie la care s-ar fi putut utiliza elementele obținute prin folosirea tiparului în discuție. Verificarea acestei propuneri s-ar putea face doar în urma observării, cel puțin vizuale, a unui lot cât mai numeros de piese, în condiţiile în care, de cele mai multe ori, acestea sunt publicate doar prin desene și fără o descriere tehnologică.

Alte două aspecte importante care ar putea fi evidențiate în legătură cu tiparul de la București-Băneasa, Str. Gârlei ar fi, pe de o parte, importanţa analizelor arheometrice care pot oferi indicii concrete referitor la metalele care erau turnate în astfel de tipare și, pe de altă parte, experiența nemijlocită pe care o poate oferi arheologia experimentală - încercarea de a folosi un tipar cu caracteristici asemănătoare împreună cu diferite aliaje metalice. Cel puțin a doua idee rămâne deocamdată un deziderat.

Tiparul descoperit la București-Băneasa, Str. Gârlei contribuie la o mai bună circumscriere a unui grup de artefacte caracteristice secolelor VI-VII. Foarte important, prin particularitățile sale, acesta ne-a permis identificarea metalelor și aliajelor care puteau fi turnate cu astfel de tipare. Identificarea unor urme de staniu și plumb în zonele afumate ale pâlniilor de turnare confirmă în mod clar faptul că era folosit pentru turnarea unor aliaje de staniu și/ sau plumb cu puncte de topire scăzute. Piesele obținute erau elemente de mici dimensiuni, folosite ca mărgele sau pandantive, înşirate în coliere sau integrate în podoabe mai elaborate ale gâtului sau pieptului. Aceleaşi elemente le putem vedea, eventual, și reasamblate în structura unor piese mai complexe. Deși nu s-a putut stabili o corelație clară între tipare și anumite categorii de podoabe sau accesorii vestimentare, au fost făcute totuşi câteva propuneri, revizuirea caracteristicilor artefactelor metalice contemporane - cu accent pus pe compoziţia aliajului şi tehnologia de realizare - putând contribui considerabil la delimitarea mai corectă și mai exactă a pieselor care se realizau prin turnare în tipare de piatră cu dimensiuni relativ reduse. În context, premisele identificării unei corelații clare între tiparele asemănătoare celor de la București-Băneasa, Str. Gârlei sau Budureasca (cat. 2 și 9 , Pl. IV/2,3) și o categorie de piese cu caracteristici bine definite, material, aspect și funcționalitate par să fie puțin mai promițătoare. Prin particularitățile sale, tiparul ne permite să surprindem un ecou îndepărtat al podoabelor din metale prețioase bogat ornamentate cu granulație, estetica noilor piese păstrându-și valențele decorative în pofida valorii reduse a materiilor prime folosite și a originalității abordării tehnologice.

cu tiparul de la București-Băneasa, Str. Gârlei (romboidal - 2,2x1,9 cm; lunula - 2,0x1,9 cm; pește? - 1,9x1,0 cm). Cele trei piese făceau parte dintr-un colier alături de alte nouă mărgele (Grumeza și Cupcea 2020, 418, 419 fig. 5/5-7, 422-423). Și în mediul avar se cunosc câteva piese de plumb, amulete, unele cu simbolistică creștină, altele probabil cu sensuri păgâne (Vida 2002, 181-182, Taf. 3/1, 6/1,3-5, 8/5). Lista este cu siguranță incompletă.

46 Ščeglova 1999, 291-292.

47 De exemplu, o fibulă din patrimoniul Muzeului Național al Banatului din Timișoara, păstrată în Colecția Pongrácz: http:// mnab.ro/wp-content/uploads/2016/09/Fig.-3-1.jpg (adresă consultată pe 18 decembrie 2020). În cimitirul nr. 3 de la Bratei, în mormântul nr. $173 \mathrm{~s}$-a descoperit un pandantiv discoidal din potin, iar în mormântul nr. $223 \mathrm{~s}$-au descoperit două perle tot din potin: Bârzu 2010, 91 (perlele metalice), M. 173 - p. 224, Taf. 29/G173/5; M. 223 - p. 242-243, Taf. 37/G223/2. 


\section{Mulțumiri}

Mulţumim colegilor noștri Zizi Baltă (pentru analizele prin fluorescență de raze X), Constantin Haită (pentru informații referitoare la materialul din care a fost confecționată piesa), Simona Movilă (pentru desene) și Marius Amarie (pentru fotografii). De asemenea, mulțumim colegilor noștri Sorin Cleșiu, Emil Dumitrașcu, Silviu Ene, Irina Ene, Mihai Florea și Florentin Munteanu care au participat la săpăturile arheologice din anul 2013. Aceste cercetări au fost coordonate de Paul Damian, căruia îi suntem recunoscători pentru acordul dat pentru publicarea tiparului.

\section{REFERINȚE BIBLIOGRAFICE}

Anton, T., Enea, S.-C. și Vasilache, V. 2020. Câteva considerații despre un tipar de piatră descoperit la RăuceștiMunteni (com. Răucești, Neamț), în A. Melniciuc, B. P. Niculică, S. Ignătescu, S.-E. Enea (eds.), Eternitatea arheologiei: studii in onoarea profesorului Dumitru Boghian la a 65-a aniversare: 599-626. Cluj-Napoca: Editura MEGA.

Antonaras, A. Ch. 2016. Arts, Crafts and Trades in Ancient and Byzantine Thessaloniki: Archaeological, Literary and Epigraphic Evidence, Heidelberg, Propylaeum (Byzanz zwischen Orient und Okzident, Band 2). Mainz: Verlag des Römisch-Germanischen Zentralmuseums.

Bálint, C. 1993. Probleme der archäologischen Forschung zur awarischen Landnahme, în M. Müller Wille și R. Schneider (ed.), Vorträge und Forschungen: Ausgewählte Probleme europäischer Landnahmen des Früh- und Hochmittelalters, Bd. 41, Nr. 1 (Teil 1): 195-273. Sigmaringen: Jan Thorbecke Verlag GmbH \& Co.

Benea, D. 2008. Officinae plumbariae în provincia Dacia. (=Unele aspecte privind prelucrarea plumbului în provincia Dacia. Atelierele), în D. Benea (ed.), Dacia în sistemul socio-economic roman. Cu privire la atelierele meșteșugărești romane, Bibliotheca Historica et Archaeologica Universitatis Timisiensis IX: 229-255. Timișoara: Editura Excelsior Art.

Bârzu, L. 2010. Ein Gepidisches Denkmal aus Siebenbürgen: das Gräberfeld Nr. 3 von Bratei, R. Harhoiu (ed.), mit Beitragen von Eugenia Zaharia und Radu Harhoiu, Archaeologia Romanica 4. Cluj-Napoca-Bistrița: Editura Accent.

Berger, D. 2006. Steingussformen aus dem spätromanischen-frühgotischen Magdeburg. Archäometrische und experimentalarchäologische Untersuchungen zum mittelalterlichen Zinnguss an ausgewahlten Fundstücken, Unveröffentlichte Diplomarbeit. Freiberg.

Berger D. și Malliaris, M. 2014. Frühe Belege mittelalterlicher Zinngießer in Zerbst, Lkr. Anhalt-Bitterfeld. Archäologie in Sachsen-Anhalt 7: 88-134.

Berger, D., Ditmar-Trauth, G. și Wunderlich, C.-H. 2020. Der Magdeburger Gießformenfund. Herausragendes Zeugnis handwerklicher Zinngießer aus einer mittelalterlichen Metropole. Veröffentlichungen des Landesamtes für Denkmalpflege und Archäologie Sachsen-Anhalt - Landesmuseum für Vorgeschichte 76. Halle (Saale): Verlag Beier \& Beran.

Brokalakis, Y. 2012. Matrici di età protobizantina dall'Impero Bizantina, în Baldini I. și Morelli, A. L., (ed.), Luoghi, artigiani e modi di produzione nell'oreficeria antica (Ornamenta 4): 213-234. Bologna: Ante Quem Editoria.

de Callataÿ, F. 1983. Gold Jewelry, Craft, Style and Meaning from Mycenae to Constantinopolis, în T. Hackens, R. Winkes (ed.), Publications d'Histoire de l'art et d'archéologie de l'Université Catholique de Louvain - XXXVI (Aurifex 5): 185-191.

Carroll, D. L. 1974. A Classification for Granulation in Ancient Metalwork, American Journal of Archaeology 78, 1:33-39.

Ciupercă, B., Măgureanu, A., 2009. Unele observații asupra problemei tiparelor din secolele V-VII descoperite în spațiul extra-carpatic. Buletinul Muzeului Județean Teleorman. Seria Arheologie 1: 149-157.

Coman, Gh., Alaiba, R. 1980. Săpăturile arheologice de la Gura Idrici-Vaslui. Materiale și Cercetări Arheologice 14: 450-454.

Comşa, M. 1971. Quelques données concernant les rapports des territoires nord-danubiens avec Byzance aux VIe- 
VIIIe siècles (Pendants d'oreille en forme d'étoile). Revue des Études du Sud-Est Européen 9, 3: 377-390.

Constantiniu, M. 1966. Elemente romano-bizantine în cultura materială a populației autohtone din partea centrală a Munteniei în sec. VI-VII e.n. Studii și Cercetări de Istorie Veche 17, 4: 665-678.

Culică, V. 1969. Obiecte de caracter creștin din epoca romano-bizantină găsite la Pârjoaia-Dobrogea. Pontice 2: 355-371

Curta, F. și Szmoniewski, B. S. 2019. The Velestino Hoard. Casting Light on the Byzantine 'Dark Ages'. Cham: Palgrave Macmillan.

Damian, P., Oanță-Marghitu, S., Cleșiu, S., Dumitrașcu, E., Florea, M., Ene, S. și Munteanu, F. 2014. BucureștiBăneasa, Str. Gârlei nr. 1C și 1E. Cronica Cercetărilor Arheologice din România. Campania 2013, A XLVIII-a Sesiune Națională de Rapoarte Arheologice, Oradea, 5 - 7 Iunie 2014: 166-168. București: volum editat de INP.

Dănilă, N. 1982. Considerații asupra noilor materiale arheologice paleocreștine din Transilvania. Biserica Ortodoxă Română 100 (7-8): 731-742.

Diaconu, R. 2015. Un tipar pentru decorațiuni metalice din județul Neamț și câteva discuții privind unele piese similare. Marisia 31-32: 43-52.

Doncheva, S. 2015. Moulds and dies from Bulgarian Middle Ages (IX ${ }^{\text {th }}-X I V^{\text {th }}$ c.). Veliko Tărnovo: Publishing house „Faber“.

Duczko, W. 1985. The Filigree and Granulation Work of the Viking Period. An analysis of the material from Björkö, Birka. Untersuchungen und Studien V. Stockholm: Almqvist and Wiksell.

Dumanov, B. 2012. The Late Antique Workshops of Jewellery South of the Lower Danube. Direct and Indirect Evidence of Local Production, în Vagalinski, L., Sharankov, N. și Torbatov, S. (eds.), The Lower Danube Roman Limes $\left(1^{s t}-6^{\text {th }}\right.$ C. $\left.A D\right)$ : 405-428. Sofia: National Archaeological Institute and Museum, Bulgarian Academy of Sciences.

Dumitru, M., Simota, C.C., Crăciun, C. și Secelean, I. 2000. Studiu privind bonitarea și calitatea solurilor din patrimoniul Câmpului experimental Băneasa-București de 6,5 ha, Institutul de Cercetări pentru Pedologie și Agrochimie (I.C.P.A.), București.

Fiedler, U. 2010. Die slawischen Bügelfibeln von Joachim Werners Gruppe I. Bemerkungen zum Forschungsstand unter besonderer Berücksichtigung des Typs IC, în A. Măgureanu, E. Gáll (ed.), Între stepă şi Imperiu. Studii în onoarea lui Radu Harhoiu: 225-252. București: Editura Renaissance.

Garam E. 1992. Die münzdatierten Gräber der Awarenzeit, în Daim F. (ed.), Awarenforschungen, Band 1, Archaeologia Austriaca - Monographien, Band 1, Studien zur Archäologie der Awaren 4: 135-250. Wien: Institut für Ur- und Frühgeschichte der Universität Wien.

Gândilă, A. 2018. Cultural Encounters on Byzantium's Northern Frontier, c. AD 500-700. Coins, artifacts, and history. Cambridge, New York: Cambridge University Press.

Grabherr, G. și Kainrath, B. 2019. Zinn- und Bleivotive aus dem Römerzeitlichen Heiligtum auf dem Klosterfrauenbichl in Lienz in Osttirol. Archäologisches Korrespondenzblatt 49: 393-411.

Gorjunova, V. M. 1992. Novyj klad antskogo vremeni iz srednego podneprov'ja (A New Hoard of Ants from the Territory of the Middle Dnieper). Arheologičeskie Vesti 1: 126-140. St.-Petersburg.

Grumeza, L și Cupcea, G. 2020. Migration Period Graves Recently Discovered in Sânpaul. Archäologisches Korrespondenzblatt 50, 3: 413-427.

Gudea, N., Ghiurco, I. 1988. Din istoria creștinismului la români. Mărturii arheologice. Oradea: Editura Episcopiei Ortodoxe Române a Oradiei

Hânceanu, G.-D. 2015. Două piese din secolele VI -VII p. Chr. descoperite la Traian (jud. Neamț). Mousaios 20: $123-132$.

Higgins, R. 1980. Greek and Roman Jewellery, (2 ${ }^{\text {nd }}$ edition). Berkeley and Los Angeles: University of California Press.

Hunt, L.B. 1980. The Long History of Lost Wax Casting. Over Five Thousand Years of Art and Craftsmanship. Gold Bulletin 13: 63-79.

Ivanišević, V. 2018. Metal Workshops of Caričin Grad (Justiniana Prima), în J. Drauschke, E. Kislinger, K. Kühtreiber, T. Kühtreiber, G. Scharrer-Liška și T. Vida (ed.), Lebenswelten zwischen Archäologie und Geschichte. Festschrift für Falko Daim zu seinem 65. Geburtstag: 711-723. Monographien des RGZM, Band 150. Mainz: Verlag des Römisch-Germanischen Zentralmuseums.

Konstantinidi-Syvridi şi E., Kontaki, M. 2009. Casting Finger Rings in Mycenaean Times: Two Unpublished 
Moulds at the National Archaeological Museum, Athens. The Annual of the British School at Athens 104: 311-319. Liesen, B. 2006. Gussformen aus der Colonia Ulpia Traiana. Xantener Berichte 14: 225-229. Mainz: Verlag Philipp von Zabern.

Măgureanu, A. și Ciupercă, B. (2004-2005) 2007. The 6th-8th centuries metallurgical activity from Budureasca Valley. The moulds. Acta Musei Napocensis 41-42, 1: 291-318.

Măgureanu, A. 2008. Observații privind semnificaţia unor descoperiri din spaţiul extracarpatic (sec. VI-VII p.Chr.). Mousaios 13: 173-190.

Mitrea, I. 1980. Regiunea centrală a Moldovei dintre Carpați și Siret în secolele VI-IX. Carpica 12: 55-190.

Mitrea, I. 2001. Comunități sătești la est de Carpați în epoca migrațiilor. Așezarea de la Davideni din secolele V-VIII. Bibliotheca Memoriae Antiquitatis 9. Piatra-Neamț: Editura „Constantin Matasă”.

Nestor, I. și Nicolaescu-Plopșor, C.S. 1938. Der völkerwanderungszeitliche Schatz Negrescu. Germania 22: 33-41. Oanță-Marghitu, R. 2006. Argamum între Imperiul Roman târziu și „,barbari”. Obiectele mărunte ca ipostaze ale comunicării, în M. Mănucu-Adameșteanu (ed.), Orgame/Argamum. Supplementa I. A la recherche d'une colonie. Actes du Colloque International „,40 ans de recherche archéologique à Orgamè/Argamum”, Bucarest-TulceaJurilovca, 3-5 octobre 2005: 345-373. București: Editura AGIR.

Oanță-Marghitu, R. (ed.). 2018. Aurul şi argintul antic al României, Catalog de expoziție, Muzeul Național de Istorie a României, București. Râmnicu-Vâlcea: Editura Conphys. [=English version: Oanță-Marghitu, R. (ed.). 2019. The Ancient Gold and Silver of Romania. Exhibition Catalogue, Muzeul Național de Istorie a României, București. Râmnicu-Vâlcea: Editura Conphys.]

Oanță-Marghitu, R. 2018a. Metalele prețioase în Antichitatea Târzie și Evul Mediu Timpuriu, în R. Oanţă-Marghitu (ed.), Aurul și argintul antic al României, Catalog de expoziție, Muzeul Naţional de Istorie a României: 138-175. Râmnicu-Vâlcea: Editura Conphys.

Oanță-Marghitu, S., Dumitrașcu, E., Ene, S., Bălășescu, A., Vasile, G., Cleșiu, S. și Muntenu, F. 2016. „Funeral” and „domestic” in the Late Iron Age settlement at București-Băneasa, Strada Gârlei (Southern Romania), în F. Gogâltan și S.-C. Ailincăi (ed.), Settlements of Life and Death. Studies from Prehistory to Middle Ages. Proceedings of an International Colloquium Tulcea, 25 th $28^{\text {th }}$ of May 2016: 273-312. Cluj-Napoca: Editura MEGA.

Ormándy, J. 1995. Granulációs díszítés ávár kori tárgyakon. Gúla- és lemezgömbcsüngős arany fülbevalók. $A$ Móra Ferenc Múzeum Évkönyve: Studia Archaeologica 1: 151-182.

Popescu, E. 1994. Les antiquités paléochrétiennes d'Histria, în Christianitas daco-romana. Florilegium studiorum: 306-396. București: Editura Academiei Române.

Preda, C. 1967. Tipar pentru bijuterii din secolul al VI-lea e.n. descoperit la Olteni (r. Videle, reg București). Studii și Cercetări de Istorie Veche 18, 3: 513-520.

Rodnikova V. E. 2011, Ženskij kostjum dneprovskih plemen v epohu velikogo pereselenija narodov: sovremennoe sostojanie issledovanij, în Novye issledovanija po arheologii stran SNG i Baltii. Materialy školy molodyh arheologov: 239-265 Moskva: IA RAN

Roth, H. 1986. Kunst und Handwerk im frühen Mittelalter. Archäologische Zeugnisse von Childerich I. bis zu Karl dem Grossen. Stuttgart: Theiss Verlag.

Ščeglova O. A. 1999. Ženskij ubor iz kladov «drevnostej antov»: gotskoe vlijanie ili gotskoe nasledie?. Stratum plus. Arheologija i kul'turnaja antropologija 5: 287-312.

Schmitz, W. 1993. „Alles Unheil halte fern!“‘. Zu einigen Gußformen für Amulette aus römischer Zeit. Bonner Jahrbuch 193: 45-68.

Schwarcz D. și Varga Z. 2010. Metalwork in the Early Avar Period: Granulation, Filigree - Imitation. Tyragetia s.n., IV (XIX), 1: 208-223.

Stoica, L., Ionescu-Ghinea, N., Ionescu, D., Luminea, C., Iliescu, P. și Georgescu, M. 1999. Atlas-ghid. Istoria și arhitectura lăcașurilor de cult din București, I. București: Editura ERGOROM'79.

Székely, Z. 1971. Élements byzantins dans la civilisation matérielle des VI $-\mathrm{VII}^{\mathrm{e}}$ siècles dans le sud-est de la Transylvanie. Dacia N.S. 15: 353-358.

Szmoniewski, B. S. 2002. Production of early medieval ornaments made of non-ferrous metals: dies from archaeological finds in North-East Romania. Acta Archaeologica Carpathica 37: 111-135.

Tănase, D. 2010. Prelucrarea metalelor în lumea barbară la Dunărea Mijlocie și Inferioară în secolele VI-VII. Timişoara: Editura Excelsior Art.

Tănase, D. 2021. Craftsmen and Jewelers in the Middle and Lower Danube Region (6th to 7th Centuries). Leiden, 
Boston: Brill.

Teodor, D. Gh. 1978. Teritoriul est-carpatic în veacurile V-XI e.n. Contribuții arheologice și istorice la problema formării poporului român. Iași: Editura Junimea.

Teodor, D. Gh. 1981. Romanitatea carpato-dunăreană și Bizanțul în veacurile V-XI e.n.. Iaşi: Editura Junimea.

Teodor, D. Gh. 1984. Civilizația romanică la est de Carpați în sec. V-VII e.n. Așezarea de la Botoșana-Suceava. București: Editura Academiei RSR.

Teodor, D. Gh. 1995. Cercei cu pandantiv stelat din secolele VI-VIII d. Hr. în spațiul carpato-danubiano-pontic. Arheologia Moldovei 18: 187-206.

Teodor, D. Gh. 1996. Meșteșugurile la nordul Dunării de Jos în secolele IV-XI d.Hr. Iași: Editura Helios.

Teodor, D. Gh. 2005. Tipare din secolele VI-XI d.Hr. în regiunile Carpato-Nistriene. Arheologia Moldovei 28: 159-174.

Teodorescu, V. 1972. Centre meșteșugărești din sec. V/VI-VII e.n. în București. București - Materiale de Istorie şi Muzeografie 9: 73-99.

Vida, T. 2002. Heidnische und christliche Elemente der awarenzeitlichen Glaubenswelt, Amulette in der Awarenzeit. Zalai Múzeum 11: 179-209.

Wolters, J. 1981. The Ancient Craft of Granulation. A Re-assessment of Established Concepts. Gold Bulletin 14, 3: 119-129.

Zerres, J. 2016. Ein frühmittelalterliches Grab mit einer zweiteiligen Gussform aus Rüsselsheim-Hassloch (Lkr. Groß Gerau). Archäologisches Korrespondenzblatt 46, 1: 121-132.

\section{LiST OF PLATES}

Pl. I. - 1. The northern zone of Bucharest and the nearby region during the interwar period (Stoica et al. 1999, 180); 2. The northern zone of Bucharest today (Google maps)

Pl. II. - Bucharest-Băneasa, str. Gârlei. The location of the archaeological site (1. Google Maps; 2. MNIR Archive) Pl III. - The stone mould discovered at Bucharest-Băneasa, str. Gârlei, MNIR Inv. No. 378564 (1. Photos by Marius Amarie; 2. Drawing by Simona Movilă).

Pl. IV. - 1. The stone mould discovered at București-Băneasa, Str. Gârlei, structure; 2. Stone mould, Budureasca, Prahova County (cat. 2) (Măgureanu, Ciupercă 2007, 318, fig. 10); 3. Stone mould, Budureasca, Prahova County (cat. 9) (MNIR inv. 106661, photo by Marius Amarie); 4. Earring with pyramidal pendant of the Szegvár type (Bálint 1993, 250, Abb. 2b); 5. Earring with pyramidal pendant of the Deszk type (Bálint 1993, 250, Abb. 2c).

Pl V. - 1. The hoard from Coşovenii de Jos, Dolj County ( $7^{\text {th }}$ century AD), photo by Marius Amarie. 2. Details of the fibula. 3-4. Details of the two earrings.

RODICA OANTTĂ-MARGHITU

Muzeul Național de Istorie a României e-mail: rodicamarghitu@yahoo.com

SORIN OANȚĂ-MARGHITU

Muzeul National de Istorie a României e-mail: sorinoanta@yahoo.com 

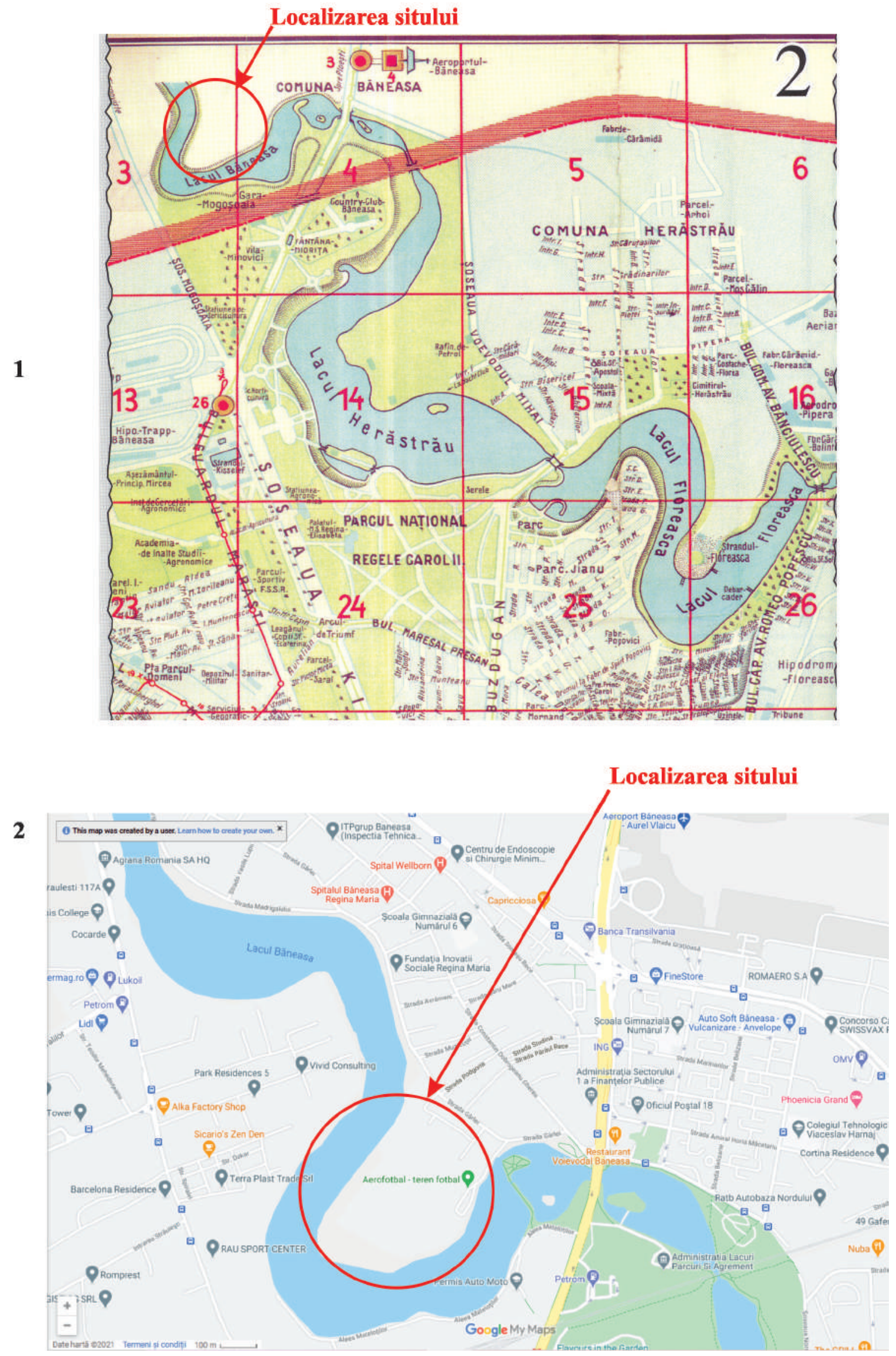

Pl. I. - 1. Zona de nord a Bucureștiului și împrejurimile în perioada interbelică (Stoica et al. 1999, 180); 2. Zona de nord a Bucureştiului în prezent (Google Maps) 

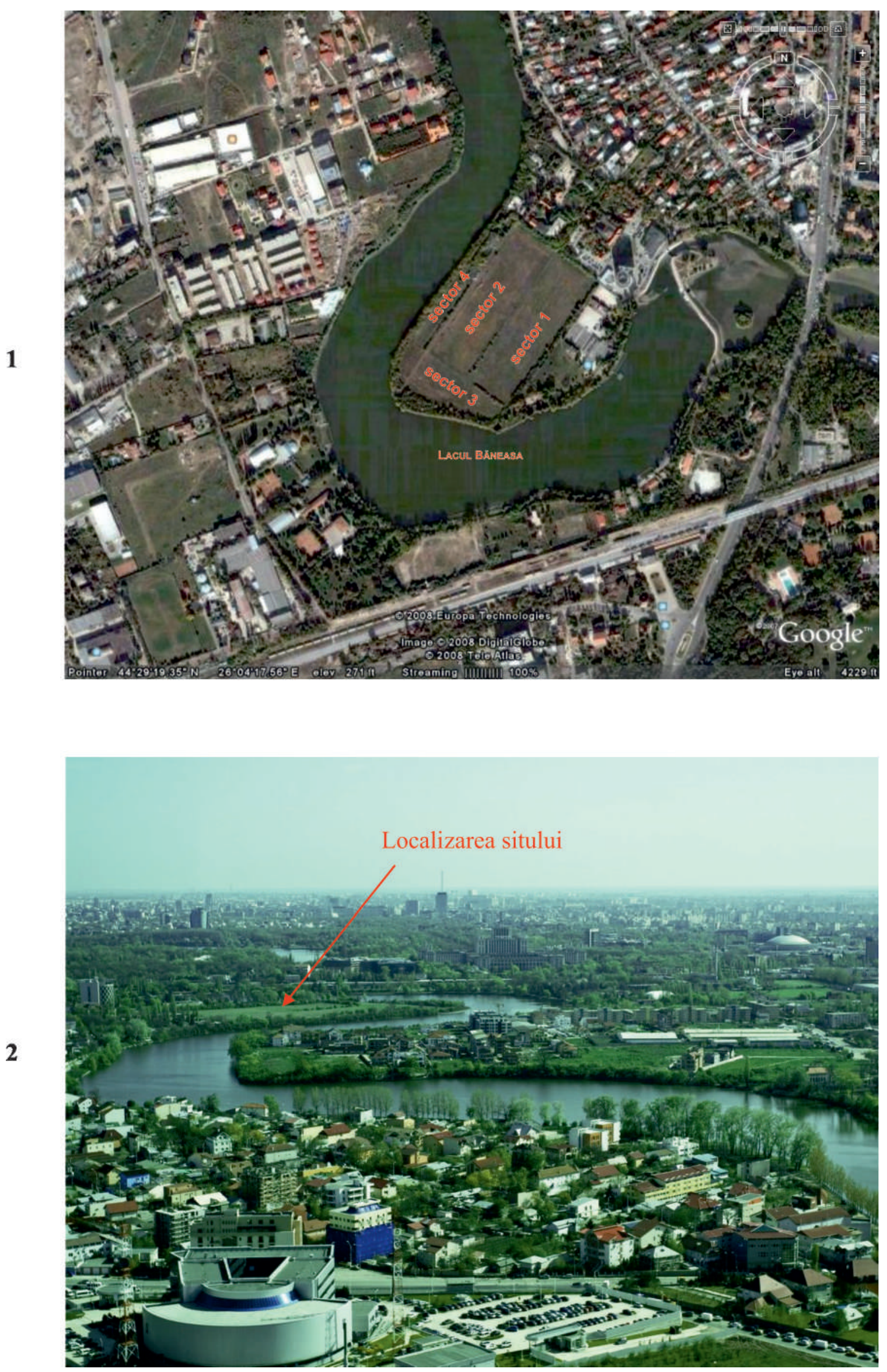

Pl. II. - București-Băneasa, Str. Gârlei. Localizarea sitului arheologic (1. Google Maps; 2. Arhiva MNIR) 

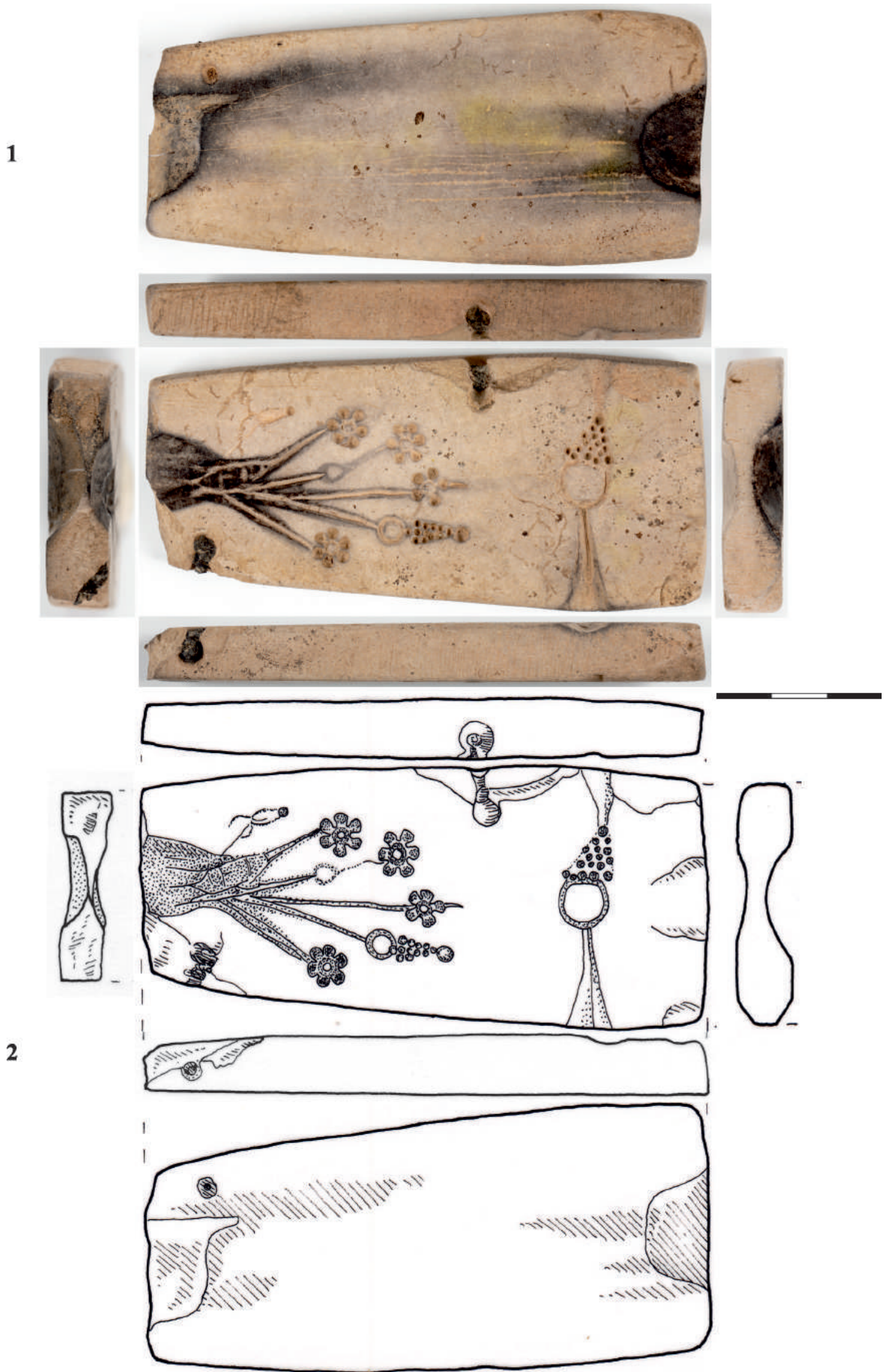

Pl. III. - Tiparul de piatră descoperit la București-Băneasa, Str. Gârlei, MNIR inv. 378564 (1. Fotografii realizate de Marius Amarie; 2. Desen realizat de Simona Movilă) 

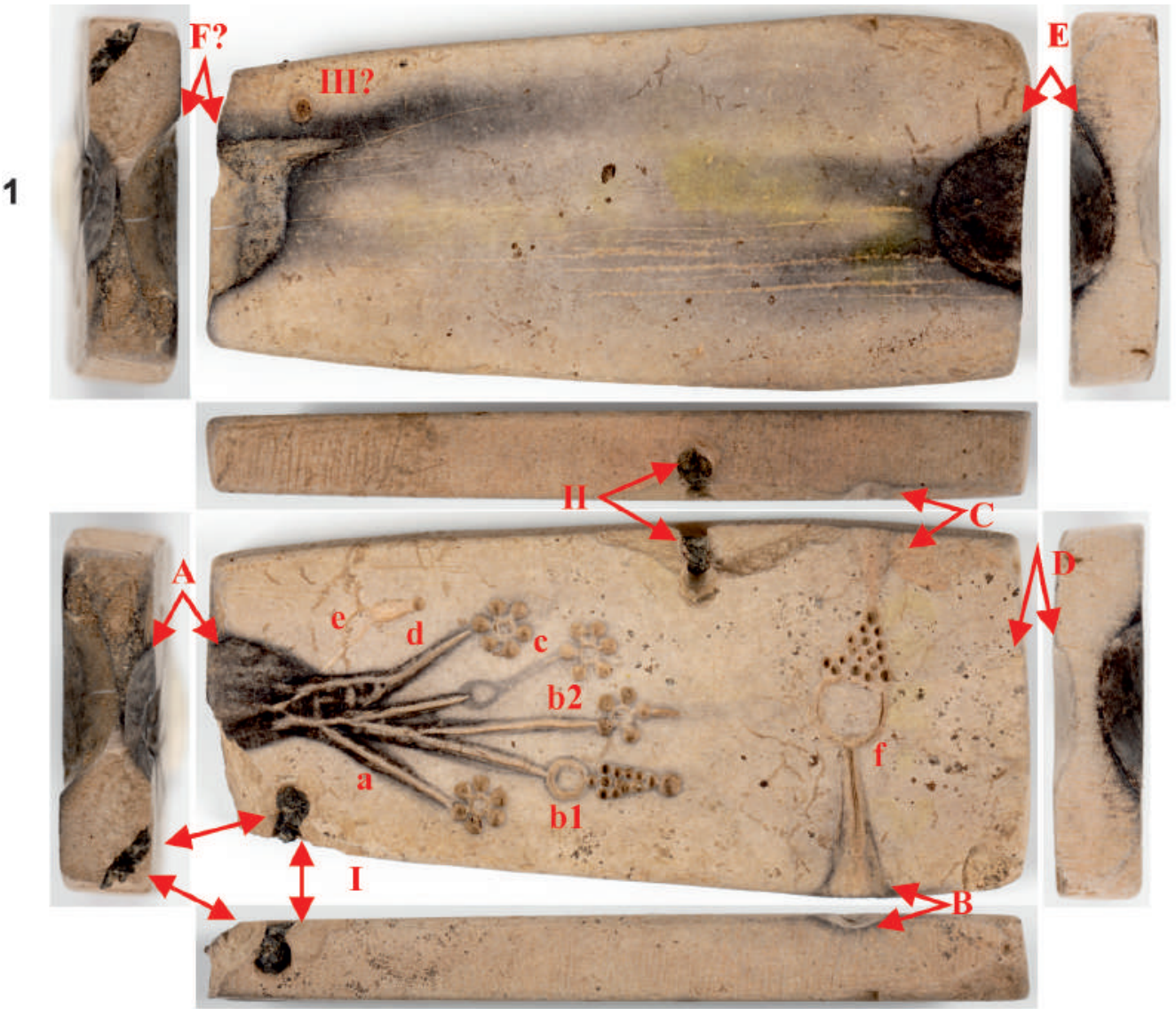

2
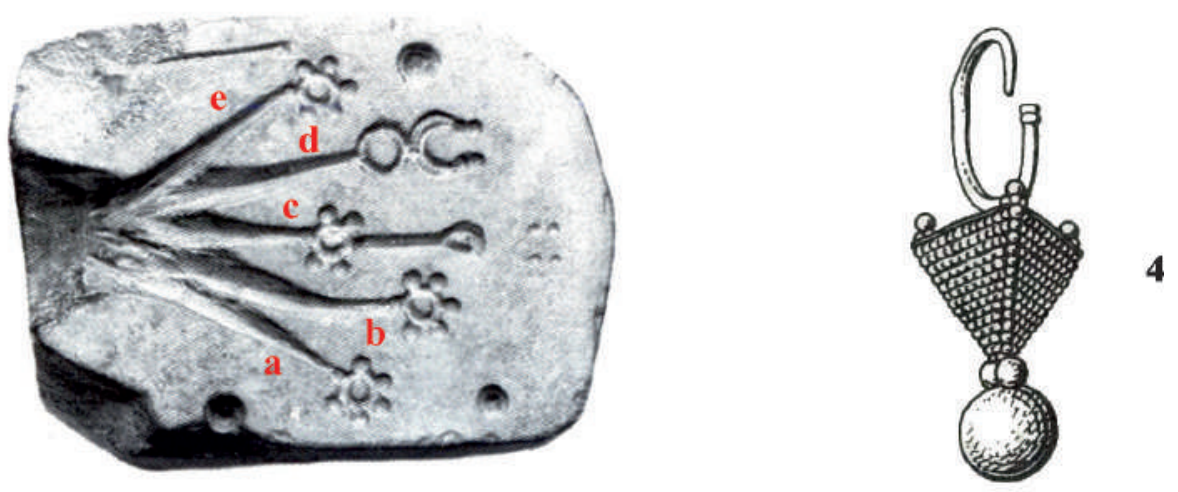

3
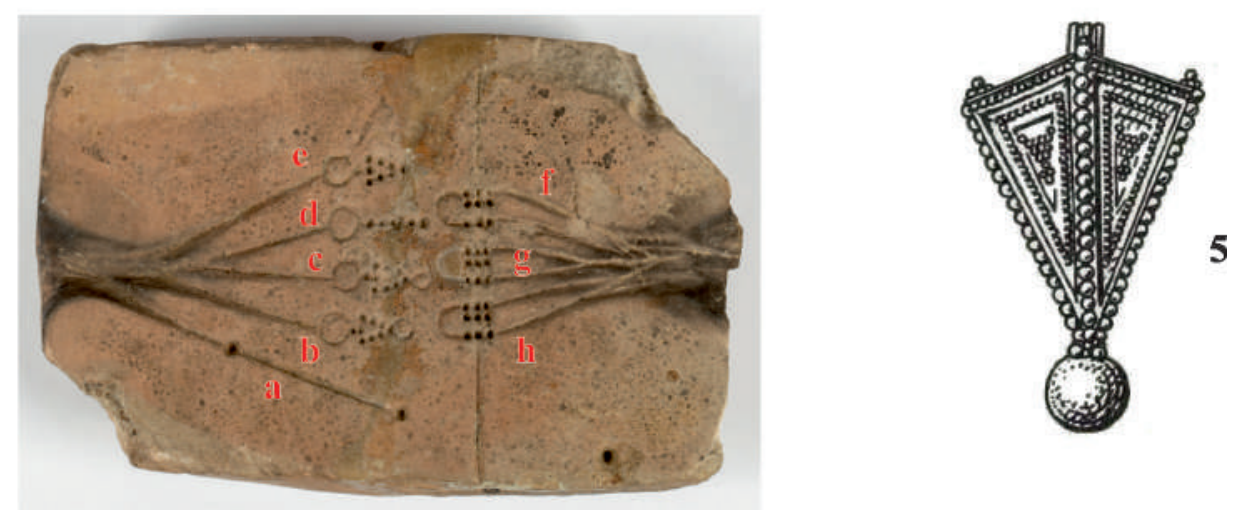

Pl. IV. - 1. Tiparul de piatră, București-Băneasa, Str. Gârlei, structură; 2. Tipar de piatră, Budureasca, jud. Prahova (cat. 2) (Măgureanu, Ciupercă 2007, 318, fig. 10); 3. Tipar de piatră, Budureasca, jud. Prahova (cat. 9) (MNIR inv. 106661, fotografie realizată de Marius Amarie); 4. Cercel cu pandantiv piramidal de tip Szegvár (Bálint 1993, 250, Abb. 2b); 5. Cercel cu pandantiv piramidal de tip Deszk (Bálint 1993, 250, Abb. 2c). 

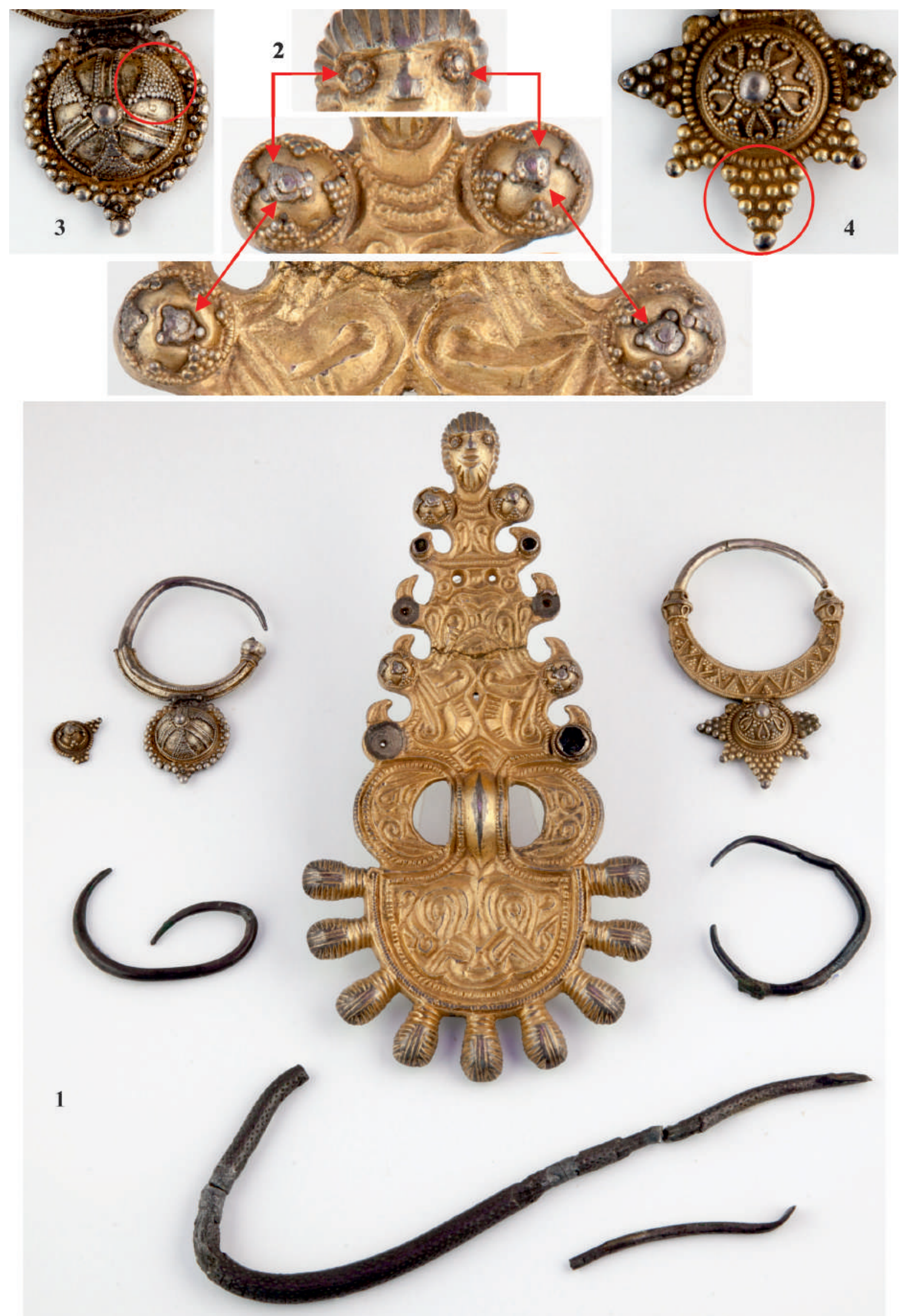

Pl. V. - 1. Ansamblul tezaurului de la Coșovenii de Jos, jud. Dolj, sec. VII p.Chr. (fotografie realizată de Marius Amarie); 2. Detalii din structura fibulei; 3-4. Detalii cu cei doi cercei. 
